\title{
THERMAL TRANSFORMATION OF SOIL ORGANIC MATTER BY NATURAL FIRES AND LABORATORY- CONTROLLED HEATINGS
}

\author{
F. J. GONZÁLEZ-VILA \\ Instituto de Recursos Naturales y Agrobiologia, \\ C.S.I.C. \\ P.O. Box 1052, \\ 41080 Seville \\ Spain
}

\section{G.ALMENDROS}

Centro de Ciencias Medioambientales, C.S.I.C.

Serrano, $115 \mathrm{~B}$, 28006 Madrid

Spain

Key words: soil organic matter, black carbon, ${ }^{13} \mathrm{C}$ - and ${ }^{15} \mathrm{~N}-\mathrm{NMR}$, pyrolysis-GC/MS, wildfires, controlled heating, charred residues, browning products, $\mathrm{C}$ and $\mathrm{N}$ sequestration, chemical degradations, forest ecosystems, fulvic acids, humic acids, humin, humus, infrared spectroscopy, laboratory simulations, lipids, melanoidins, peat

Abstract: The results of a multi-approach analysis on the effects that wildfires exert on soil organic matter (SOM) properties are presented. The methods used included wet chemical oxidation and thermal degradation by flash pyrolysis, as well as Fourier-transformed infrared (FT-IR) and solid-state ${ }^{13} \mathrm{C}$ and ${ }^{15} \mathrm{~N}$ nuclear magnetic resonance (NMR) spectroscopies. Such destructive and non-destructive analytical techniques were used for the assessment of heat effects to a molecular level applied to representative Spanish forest ecosystems and for the study of the alteration of different organic materials in the course of progressive heating in laboratory simulation experiments. The materials studied included: whole soils and sapric peat, isolated soil humic fractions, lignocellulosic biomass and preparations of cellulose.

Among our findings, it can be emphasized: (i) the importance of the abiotic transformation of aliphatic precursors into aromatic macromolecules under present-day environmental conditions, (ii) a thermal neoformation of heterocyclic $\mathrm{N}$-forms, (iii) changes in the solubility properties of the soluble and colloidal SOM fractions, (iv) a preferential loss of oxygen-containing functional groups and $O$-alkyl aliphatic structures, and (v) changes in the SOM macromolecular structure, probably related to the accumulation of a resistant alkyl moiety.

In general, our results from laboratory experiments agreed with those obtained from soils affected by wildfires in different Continental Mediterranean forest formations. The results are discussed in terms of the natural stabilization mechanisms of the most refractory SOM forms, which is of particular interest in the study of the global $\mathrm{C}$ and $\mathrm{N}$ biogeochemical cycles. 


\section{Introduction}

\subsection{Effect of fire on soil properties and soil organic matter composition. State of the art}

The soil is the largest pool of organic carbon in the Earth's Surface (Batjes, 1996). It doubles that present in the atmosphere $(760 \mathrm{Pg})$ and is about $2-3$ times larger than that in living organisms in the whole terrestrial ecosystems (Post, 1990; Prentice et al., 2001).

From the qualitative point of view, SOM influences physical and chemical soil properties as well as the availability of nutrients for microbial and plant growth. Consequently, SOM can be described as an active environmental compartment in which the biogeochemical processes have a direct effect on crop production and agroforestry yields and on the quality of the environment by affecting the composition of the soil solution, also related to surface and groundwater water quality. Depending on the turnover time in soil, different conceptual pools of SOM can be distinguished: active SOM (fast recycling) that remain in soil for years or some decades, and passive or refractory SOM, remaining in soil for centuries to millennia (Balesdent and Mariotti, 1996). Small deviations in the different C pools in the soil may have a significant effect on the global climate change. Thus, their proper identification and quantification is necessary both to be able to forecast $\mathrm{C}$ turnovers in soil as well as for a better understanding of the global $\mathrm{C}$ cycle.

Wildfires, as well as practices based in the application of fire, like prescribed burnings of brushwood or crop residues, are likely to affect the quality and quantity of SOM pools. Both factors are important components in the natural and managed Mediterranean ecosystems. The research about the relationship between wildfires and human activities and the questioned use of prescribed burnings has been recently reviewed (Caldararo, 2002). In general, the long-term influence of fire on the physical and chemical properties of the soil may be more relevant than that from biological, geological and climatic factors. The destruction of the vegetation is often responsible for intense soil erosion, but even in burned forests on flat sites, fire can lead to severe alteration of soil properties, including changes in the total amount of organic C, N, litter, humus fractions and water-repellent substances (Savage et al., 1972; Viro, 1974; de Bano et al., 1976, 1977a,b; Dunn and Conrad, 1977; Giovannini et al., 1983, 1987,1988; Giovannini and Lucchesi, 1984; Almendros et al., 1984a; Vega, 1985, 1986; Vega et al., 1985). In addition, it has been found that most structural features of the SOM became altered to a molecular level (Almendros et al., $1984 \mathrm{~b}, 1988,1990,1992)$. On the other hand, wildfires are important in the longterm sequestration of $\mathrm{C}$ and $\mathrm{N}$ in forest soils (Parker et al., 2001). These processes deserve more research attention and need to be better understood, since significant changes in the $\mathrm{C}$ storage potential of the soil may alter the global $\mathrm{C}$ cycle, leading to climatic uncertainties. Some fire-affected ecosystems may act as significant sinks for atmospheric $\mathrm{C}$ because vegetation fires and fuel-wood combustion transfer $\mathrm{C}$ from the relatively fast biological-atmosphere $\mathrm{C}$ cycle to the long-term geological one (Levine et al., 1995; Kuhlbusch, 1998). In particular, biomass burning lead to 
the accumulation of charred plant material, which has traditionally been studied as regards the origin of humic substances (Shindo et al., 1986a; Shindo, 1991), also large amounts of highly refractory organic matter, collectively referred to as "black carbon", is formed. A review on the composition, origin and fate of black carbon in soils and sediments has been recently published by Derenne and Largeau (2001).

Black carbon is mainly produced by vegetation fires, in the form of on-site residues or shoot, and is widely distributed in the Earth's surface (Goldberg, 1985; Gustafsson and Gschwend, 1998). Black carbon may account for a substantial fraction of the total organic C (up to 45\%) in some soils (Skjemstad et al., 1996, 1997; Kuhlbusch et al., 1996; Haslam et al., 1998; Schmidt et al., 1999). There is also an indirect evidence that this charred material may explain the origin of highly aromatic HAs in volcanic ash soils (Shindo et al., 1986b; Hatcher et al., 1989; Haumaier and Zech, 1995; Golchin et al., 1997a,b). The presence of these stable $\mathrm{C}$ forms in HA have been associated to the release of benzenepolycarboxylic acids during laboratory controlled degradations (Glaser et al., 1998). It has been also suggested that fireinduced mechanisms may substantially contribute to the terrestrial N sink (Knicker and Skjemstad, 2000).

\subsection{The importance of laboratory simulation experiments in the research of geothermal processes}

The simultaneous occurrence of different processes during a forest fire makes extremely difficult to explain mechanisms involved in SOM transformations in burned areas. There is a dynamic balance between degradation and generation of organic substances, which depends both on temperature and on heating time. Nevertheless, phenomena such are the selective destruction of humus fractions, chemical alteration in SOM properties, and external inputs of charcoal and terrified lignocellulose from the vegetation has been widely documented. In summary, we may said that a standard thermal treatment lead to: (i) selective destruction of the least resistant structures, (ii) condensation resulting in compounds not existing in the original sample, (iii) thermal diagenetic alteration of the structure of macromolecules (mainly but not only in oxygen-containing functional groups), (iv) structural changes with a bearing on the solubility properties-speciation status-both of high- and low-molecular weight substances, and finally (v) a substantial input of charred, refractory, plant derived biomass incorporated to the soil (Almendros et al., 1990).

Laboratory simulation experiments involving the heat of whole soil or peat samples, humic fractions, lignocellulosic materials, isolated preparations of plant macromolecules, etc., under conditions comparable to those recorded for different types of forest fires have yielded information which can be more unambiguously interpreted (de Bano et al., 1970; Savage et al., 1972; Savage, 1974; Scholl, 1975; Almendros et al., 1984b, 1988, 1990, 1992; Fernández et al., 1997). However, the influence of the facts described above, mainly the destruction of the least resistant compounds, the formation of new structures by condensation and the thermal diagenetic alteration of the macromolecules, cannot be properly understood when the 
heated material is studied and analyzed as a whole; and the above-indicated effects on the solubility properties remain unknown, even when a detailed chemical fractionation of the organic matter is performed.

In general, the changes on the SOM caused by fire or heat allow the definition of "pyromorphic humus". This is composed by rearranged macromolecular substances of weak colloidal properties and an enhanced resistance to the biological degradation, as inferred from laboratory incubation experiments with natural or laboratoryheated samples (Almendros et al., 1984b).

Concerning the effects of fires on biomass, most of the studies have been focused to the thermal degradation of lignocellulosic material. It has been demonstrated that forest fires or the controlled burnings of crop residues induce a series of interand intra-molecular reactions leading to condensed materials with chaotic structure and a close resemblance with humic substances (Almendros et al., 1992; Golchin et al., 1997b; Yanagita et al., 1997). In addition, other biomolecules such as peptides or lipids may experience major alterations as consequence of the fire. In fact, laboratory experiments have proved that, under thermal conditions, even lipids in young sediments may polymerise into kerogen-like matter (Shyoya and Ishiwatari, 1983).

The well-known formation of melanoidins by heating of sugar- and amino acidcontaining mixtures is frequently taken as a model process for the formation of humiclike macromolecules through abiotic reactions (Maillard, 1916; Ellis, 1959), and this phenomena may occur in lignin-lacking sedimentary media affected by external or geothermal heat sources (Dennis et al., 1982; Almendros et al., 1990). The geochemical aspects of the Maillard reaction have been reviewed by Ikan et al. (1996). In addition, the formation of carbohydrate-dehydration brown-coloured products from $\mathrm{N}$-lacking materials (referred to as pseudomelanoidins) has been described in model systems from polysaccharides as from sugars, both in solution and as a result of dry heating (Popoff and Theander, 1972, 1976; Feather and Harris, 1973; Almendros et al., 1989, 1997).

\subsection{Analytical approaches to monitor changes in the molecular composi- tion of organic materials affected by heating processes}

The research at a molecular level of the transformations of sedimentary organic matter under natural or simulated conditions is a complicated task, which requires the use of appropriate analytical approaches, bearing in mind the limitations inherent to the multicomponent mixtures.

The use of conventional physico-chemical analytical procedures allows us to evaluate the incidence degree of thermal processes on the bulk properties of the organic material. However, in order to be able to monitor structural changes at a molecular level, a combination of both destructive (such are chemical and thermal degradation procedures) and non-destructive methods (mainly spectroscopic) is required.

Infrared (IR) spectroscopy is especially responsive to $\mathrm{O}$ - and $\mathrm{N}$-containing SOM functional groups, but its resolution is largely limited in the case of heterogeneous 
macromolecular material. Nevertheless, resolution enhancement based on mathematical processing of spectral data, yield valuable information in the case of SOM where the broad peaks are mostly due to the overlapping of a series of neighbouring bands (Wang and Griffiths 1985; Yang et al., 1985; Gerasimowicz et al., 1986). This approach has been found especially helpful for the present research, the progressive maturation, coalification or thermal treatment is known to lead to featureless spectral profiles of macromolecular materials.

A realistic evaluation of the different structural units in SOM can be achieved by the use of ${ }^{13} \mathrm{C}-\mathrm{NMR}$ spectroscopy under quantitative acquisition conditions (Wilson, 1987; Fründ and Lüdemann, 1989; Preston, 1992; Kögel-Knabner, 1997). Such a technique has been found suitable for determining the presence of structural moieties (viz. $O$-alkyl structures) otherwise underestimated by oxidative degradation methods. Among the advantages of this technique is that complex macromolecular structures can be examined directly, with no need of previous laboratory fractionations.

In contrast to ${ }^{13} \mathrm{C}-\mathrm{NMR}$, the application of solid-state ${ }^{15} \mathrm{~N}-\mathrm{NMR}$ to $\mathrm{N}$-containing geomacromolecules has been hampered by the fact that its sensitivity is approximately 50 times lower than that of ${ }^{13} \mathrm{C}-\mathrm{NMR}$. Consequently, ${ }^{15} \mathrm{~N}-\mathrm{NMR}$ is more successful when ${ }^{15} \mathrm{~N}$-enriched materials are used (Benzing-Purdie et al., 1983, 1986; Thorn et al., 1989; Cheshire et al., 1990; Almendros et al., 1991; Knicker and Lüdemann, 1995; Clinton et al., 1996; Potthast et al., 1996; González-Vila et al., 2001a). Preston et al. (1986) was the first author to publish a solid-state ${ }^{15} \mathrm{~N}-\mathrm{NMR}$ spectrum of humic material from a peat with natural ${ }^{15} \mathrm{~N}$-abundance and $\mathrm{N}$ content ca. $4 \%$. Afterwards, and aided by instrumental developments and a systematic optimisation of solid-state ${ }^{15} \mathrm{~N}-\mathrm{NMR}$ acquisition parameters, this technique has been routinely applied to organic $\mathrm{N}$ in soil systems at natural ${ }^{15} \mathrm{~N}$ abundance (Knicker et al., 1993, 1997, 2000, 2002; Knicker and Hatcher, 1997; Knicker, 2000). Recent studies demonstrated that solid-state ${ }^{15} \mathrm{~N}-\mathrm{NMR}$ spectroscopy has the potential to become a powerful non-degradative tool to reveal the nature of biologically and chemically recalcitrant organic material in soils and sediments.

More than half of the N in SOM still consists of "unknown" structures therefore investigations on the speciation patterns of $\mathrm{N}$ are of indubitable environmental interest (Schnitzer, 1985). In particular, recent NMR studies on the occurrence of organic $\mathrm{N}$ forms in natural samples have shown the dominance of amide forms in practically all types of sedimentary organic matter (Derenne et al., 1993; Nguyen and Harvey, 1998; Knicker et al., 1995; Knicker, 2000). Thus, the classical assumption that the recalcitrant $\mathrm{N}$-forms in humic substances largely consisted of heterocyclic compounds (Shulten and Schnitzer,1998) has not been evidenced by NMR techniques at least in SOM formed predominantly under biological processes.

Concerning degradative techniques, classical approaches based on wet chemical degradation followed by gas-chromatography-mass spectrometry (GC/MS) have lead to considerable progress in the knowledge SOM at a molecular level (Schnitzer, 1977; Stevenson, 1982; Hayes et al., 1989). Such destructive methods, however, require the use of drastic degradation reagents and high temperatures that often lead to biased quantitative results, or to the formation of undesirable by-products. It is also probable that some structures (e.g. carbohydrate-like) remain "invisible" since 
they do not contribute with diagnostic units to the molecular assemblages obtained by wet chemical degradation methods (Maximov et al., 1977). This circumstance is often attributed to the fact that the strength of the bonds within humic units is similar to that of the internal inter-atomic bonds. The above problems concur to large extent in the case of SOM affected by heating processes, therefore wet chemical methods have not been extensively used for the molecular characterization of these recalcitrant substances (Almendros et al., 1988).

The use of analytical pyrolysis became very popular in the last two decades. This technique involves the thermolytic degradation of macromolecular materials into small fragments and further analysis by GC/MS. Under certain conditions, it has been assumed that these fragments are representative units of the original macromolecules.

In particular, pyrolysis-GC/MS has proved to be a valuable tool for the structural analysis of lignins, where the diagnostic methoxyl substitution patterns can be recognised in the pyrolysis products (Martin et al., 1979). Likewise, pyrolytic techniques have been widely used for the structural characterisation of humic substances, coals and kerogens (Martin and González-Vila, 1983; Del Río et al., 1993; Almendros et al., 1993,1998,1999; González-Vila et al., 2001b). It is also well established that pyrolysis of polysaccharides yields diagnostic secondary products useful to monitor the carbohydrate signature of geomacromolecules (Ralph and Hatfield, 1991; Almendros et al., 1997).

\subsection{Workplan and objectives}

In order to elucidate the mechanisms involved in the alteration and accumulation of SOM in soils and sediments subjected to thermal stress (abiotic diagenetic pathways), complementary approaches have been undertaken:

\subsubsection{Analytical description of humus formations in forest ecosystems affected by wildfires}

A selection of soils from representative continental Mediterranean Spanish ecosystems were used to identify typical characteristics of the thermally altered SOM. This was performed by comparison of the chemical composition of SOM from neighbor sites, affected or not by fire. With this approach, it is possible to assess the extent of the changes exerted by fire, but its use to elucidate the processes involved in such transformations is limited. The pre-existing organic matter is transformed and, at the same time, mixed with external inputs of transformed plant material.

\subsubsection{The transformation of humus after heating whole soils under laboratory conditions}

In order to distinguish between the "fire intrinsic effects" and those due to external inputs, laboratory heating of soil samples was carried out in parallel experiments. After heating whole soil samples, the different SOM fractions were isolated and purified. As the mineral moiety of soils may hamper the application of several techniques for SOM research, some experiments were carried out with organic soil (e.g. 
a sapric peat). The high maturity degree of the organic matter, the low interference by mineral fractions and the possibility to study ${ }^{15} \mathrm{~N}$ transformation at natural abundance make this material highly suitable to monitor specific processes with sufficient analytical accuracy.

\subsubsection{Thermal alteration of isolated humic fractions and plant biomass after progressive heating}

The information obtained from the above experiments is still relatively limited since the SOM fractions are conventionally defined by criteria based on their solubility in different types of organic, alkaline and acid extraction reagents. Consequently, and due to the drastic changes in solubility properties in soil organic fractions subjected to heating, a series of experiments in progressively simplified model systems are required.

This experimental approach included the study of:

(a) Isolated humic acids (HA) and fulvic acids (FA) mixed with organic matterfree soil.

(b) Lignocellulosic biomass consisting of ${ }^{15} \mathrm{~N}$-enriched plant material (Lolium rigidum Gaud.).

(c) Standard preparations of cellulose, the major plant constituent.

\section{Material and methods}

\subsection{Samples studied}

In this work, the natural soils affected by wildfires studied were: (i) Dystric Xerochrepts under pine and oak forest from Central Spain (Almendros et al., 1984a, 1988, 1990, 1992); (ii) Typic Xerochrept under pine forest from Southern Spain (GonzálezVila et al., 2002); (iii) Calcaric Cambisol under pine forest from Central Spain (Tinoco, 2000) and (iv) Umbrihumic Umbrisol and Epidystric Cambisol. under pine forest from Central Spain (Tinoco, 2000).

The laboratory simulation experiments were done using: (i) samples of whole soil from pine and oak forests from central Spain (Almendros et al., 1984b, 1988); (ii) isolated HA and FA from soil under oak forest (Almendros et al., 1990, 1992); (iii) sapric peat from Northern Spain (Almendros et al., 2002); (iv) ${ }^{15} \mathrm{~N}$-enriched ryegrass (Lolium rigidum) biomass (Knicker et al., 1996; González-Vila et al., 2001c) and (v) crystalline cellulose (Almendros et al., 1997).

\subsection{Laboratory simulation experiments}

Simulation experiments were based on the methods and results described by Savage (1974), Scholl (1975), De Bano et al. (1976) and Almendros et al. (1984b). The standard experimental conditions for the laboratory heating is described in detail in 
Almendros et al. (1990). The isothermal heating method chosen was found to be more reproducible and easier to control than the alternative one using constant time and variable temperature (Almendros et al., 1992). The experiments were carried out either in an electric muffle (using 100-mL crucibles with whole soils) or in Wosthöff furnace under $\mathrm{a} \mathrm{CO}_{2}$-free air flow connected to a Carmhograph-12 analyzer to measure the $\mathrm{CO}_{2}$ production (isolated humic fractions or standard materials: cellulose, ryegrass and whole peat). In the case of isolated humic fractions (HA and FA), the samples were ground to pass a $100-\mu \mathrm{m}$ screen and mixed with mineral substratum (the $>0.2-$ $\mathrm{mm}$ fraction of the original soil treated with hydrogen peroxide). Heating the humic substances without mineral substratum was found not appropriate, leading to very heterogeneous preparations (charred surface samples and less transformed in the core) with a poor reproducibility because the influence of the amount and form of the sample pile.

Up to 10 replications were prepared using $10-\mathrm{mL}$ porcelain boats containing $5 \mathrm{~g}$ of soil and $100 \mathrm{mg}$ of sample. After isothermal heating at $350{ }^{\circ} \mathrm{C}$ during variable periods between 60-150 s (HA and FA), 30-90 s (ryegrass), and 30-180 s (cellulose and peat), the boats were stored in a dessicator. Three of the above heated samples were used for triplicate quantitative determination of the residual fractions, another two for the proximate analysis of the total $\mathrm{C}$ content, and the remainder for a subsequent characterization of the transformed material.

\subsection{Bulk soil characteristics and organic matter analyses}

The cation exchange capacity was determined using the method of Mehlich (1948), total $\mathrm{C}$ was measured with a Carmhograph-12 analyser, and the total $\mathrm{N}$ by the Kjeldahl method (USDA, 1972). The elementary composition of the isolated humic fractions was determined with a Carlo Erba CHNS-O-EA1108 microanalyser, using $c a$. $7 \mathrm{mg}$ sample.

The incubation experiments to monitor the respiratory activity of the soils (Guckert et al., 1968) were done using $100 \mathrm{~g}$ moistened soil at $50 \%$ of water holding capacity at the atmospheric pressure, and incubated in 500-mL closed Erlenmeyer flasks fitted with input and output tubes at $27^{\circ} \mathrm{C}$. Three replicates were done for the control and burned soils. The $\mathrm{CO}_{2}$ evolution was estimated regularly every day connecting the incubation flasks directly to a Carmhograph-12 gas analyser. During the measurement, the input tube of the flask was connected to a soda-lime column $\left(\mathrm{CO}_{2}^{-}\right.$ free air), and the output tube to the gas analyser.

\subsection{Isolation and quantification of humus fractions}

The soil lipid fraction was extracted from the samples with petroleum ether in a Soxhlet for $40 \mathrm{~h}$, and neutral and polar fractions separated in a silica gel column using successively hexane and hexane-methylene chloride 1:1. For GC/MS analysis, the polar fraction was previously methylated with diazomethane. 
The free organic matter and the so-called inherited humin (particulate organic fraction encapsulated in soil stable aggregates) were separated following Monnier et al. (1962) and Chouliaras et al. (1975) protocols respectively. The colloidal humic substances were then isolated from the dried residue by repeated extraction with $0.1 M \mathrm{Na}_{4} \mathrm{P}_{2} \mathrm{O}_{7}$ and $0.1 M \mathrm{NaOH}$. The HA (acid-insoluble fraction) was separated from the acid-soluble (FA) after precipitation with $\mathrm{HCl}$ at $\mathrm{pH} 1$. The residual heavy fraction of soil was then washed with $1 \% \mathrm{w} / \mathrm{w} \mathrm{Na}_{2} \mathrm{~S}_{2} \mathrm{O}_{4}$ and $1 M \mathrm{HCl}-\mathrm{HF}$ to get the extractable humin fraction (Merlet, 1971), this was extracted with $0.1 \mathrm{M} \mathrm{NaOH}$. The quantitative proportion (in C) of the above fractions, as well as that of the residual $\mathrm{C}$ in the soil heavy fraction (non-extractable humin), was determined with the Carmhograph-12 C analyser. The HAs were purified by $27000-g$-centrifugation at $\mathrm{pH} 12$, reprecipitated and demineralised with $1 \%$ HCI-HF (50\%). The FAs weare adsorbed on a column with insoluble polyvinylpyrrolidone (Divergan ${ }^{\circledR} \mathrm{R}$, BASF), eluted with $0.1 M \mathrm{NaOH}$ and purified by means of cation exchange chromatography, using Amberlite ${ }^{\circledR}$ IR-120 (Lowe, 1975).

\subsection{Analysis of humic acids by wet chemical degradation methods}

The isolated HA fraction was methylated (Schnitzer, 1974) and then degraded with potassium persulfate (Martín et al., 1981). The non-degraded residue was subsequently oxidized with potassium permanganate until total degradation (Matsuda and Schnitzer, 1972). Because of the partial degradation achieved with the former reagent as compared to the latter, the resulting oxidation products were considered as produced by the loosely associated and more strongly linked structural components of the humic macromolecules, respectively.

The low molecular weight degradation products were extracted with ethyl acetate, dehydrated with anhydrous $\mathrm{Na}_{2} \mathrm{SO}_{4}$, dried under $\mathrm{N}_{2}$ and then, methylated with diazomethane before GC/MS analyses.

The separation of the above lipid fractions and of the degradation products were made with a Hewlett-Packard 5992 B GC/MS system with a 25-m cross-linked OV101 capillary column. Oven temperature was programmed to increase from 100 to $270^{\circ} \mathrm{C}$ at a heating rate of $6^{\circ} \mathrm{C}$ min. Helium flow was $1 \mathrm{~mL} \mathrm{~min}^{-1}$ and the ionising voltage in the MS was $70 \mathrm{eV}$. Compound identification was based on literature data and comparisons with mass spectral libraries (NIST, Wiley).

\subsection{Analytical pyrolysis}

Pyrolysis experiments were done in a Curie-point pyrolyser (Horizon Instruments) attached to a Varian Saturn $2000 \mathrm{GC} / \mathrm{MS}$ system. The samples heated at $510^{\circ} \mathrm{C}$ of Curie-point temperature on ferromagnetic wires. The interface temperature of the pyrolysis unit was set at $250^{\circ} \mathrm{C}$ and pyrolysis time was $5 \mathrm{~s}$. The injector, equipped with a liquid $\mathrm{CO}_{2}$ cryogenic unit, was programmed from $-30^{\circ} \mathrm{C}(1 \mathrm{~min})$ to $300^{\circ} \mathrm{C}$ at $20{ }^{\circ} \mathrm{C} \mathrm{min}{ }^{-1}$. The $\mathrm{GC}$ oven was programmed from $50^{\circ} \mathrm{C}$ to $100{ }^{\circ} \mathrm{C}$ at $32^{\circ} \mathrm{C} \mathrm{min}^{-1}$ 
and then up to $320^{\circ} \mathrm{C}$ at a rate of $6{ }^{\circ} \mathrm{C} \mathrm{min}^{-1}$. The chromatographic separation was carried out with a fused-silica capillary column $(25 \mathrm{~m} \times 0.32 \mathrm{~mm})$ coated with CPSil (film thickness $0.4 \propto \mathrm{m}$ ) using helium as carrier gas.

\subsection{Spectroscopic techniques}

The IR spectra ( $\mathrm{KBr}$ pellets with $2.0 \mathrm{mg}$ sample) were acquired in with a PerkinElmer 683 spectrophotometer in the $2000-600 \mathrm{~cm}^{-1}$ range (1400 data points) and processed with the authors' program. For resolution enhancement, the method used here is based on subtracting from the raw spectrum a positive multiple of its $2^{\text {nd }}$ derivative, a procedure originally used in digital image processing (Rosenfeld and $\mathrm{Kak}, 1982$ ). The noise was reduced by 100 iterations of local smoothing by moving averages, and the factor 1500 was used to multiply the second derivative.

The solid-state ${ }^{13} \mathrm{C}$-NMR spectra were acquired with a Bruker DSX 200 instrument at frequency of $50.32 \mathrm{MHz}$ using a zirconium rotor of $7 \mathrm{~mm}$ OD with Kel-F caps. The cross polarization magic-angle spinning (CPMAS) technique was applied with a frequency of $6.8 \mathrm{kHz}$. A ramped ${ }^{1} \mathrm{H}$-pulse was used for the contact time in order to circumvent spin modulation of Hartmann-Hahn conditions. A contact time of $1 \mathrm{~ms}$ and a $90^{\circ} \mathrm{H}$-pulse width of $5.4 \mu$ s were applied. The ${ }^{13} \mathrm{C}$-chemical shifts were calibrated to tetramethylsilane $(0 \mathrm{ppm})$. Between 5,000 and 8,000 scans were accumulated with a pulse delay of $300 \mathrm{~ms}$. Prior to Fourier transformation, a line broadening of $50 \mathrm{~Hz}$ was applied. The relative distribution of $\mathrm{C}$ atoms distribution was determined with the integration routine supplied with the instrument software. The solid-state CPMAS ${ }^{15} \mathrm{~N}$-NMR spectra were acquired with a Bruker DMX 400 operating at $40.56 \mathrm{MHz}$ with a contact time of $1 \mathrm{~ms}$, a $90^{\circ}$ pulse width of $5.8 \mu \mathrm{s}$, a pulse delay of $150 \mathrm{~ms}$, and a line broadening of 100 and $150 \mathrm{~Hz}$. Between 5 and $7 \cdot 10^{5}$ scans were accumulated at a magic-angle spinning speed of $5.5 \mathrm{kHz}$. The chemical shifts were referred to the nitromethane scale $(0 \mathrm{ppm})$ and adjusted with ${ }^{15} \mathrm{~N}$-labelled glycine (-347.6 ppm).

\section{Results and discussion}

\subsection{Effects of wildfires on soil organic matter under natural conditions}

3.1.1. The influence of fire on soil's bulk characteristics and humus fractions Fire-induced changes in the soil properties and in their humic and lipid fractions, were assessed by comparing the analytical characteristics of samples collected from sites affected by fire, with those taken from neighbor places in undisturbed areas. A triplicate spatial sampling was done.

Table 1 shows the comparative analyses of both soil samples affected by fire, and the neighbor unaltered soil. The increase in the soil pH and in the amounts of most exchangeable cations has been frequently described as an effect of forest fires (Viro, 1974). Lower fertility levels to those shown in Table 1 has been observed 
Table 1. Soils affected and not affected by natural fires; bulk analyses.

\begin{tabular}{|c|c|c|c|c|c|c|c|c|c|}
\hline Ref. & Soil type & $\begin{array}{l}\text { Literature } \\
\text { reference }\end{array}$ & $\begin{array}{l}\text { Natural } \\
\text { vegetation }\end{array}$ & $\mathrm{pH}$ & $\begin{array}{l}\% \mathrm{C} \\
\mathrm{g} 100 \mathrm{~g}^{-1}\end{array}$ & $\mathrm{C} / \mathrm{N}$ & $\begin{array}{l}\text { Cation } \\
\text { exchange } \\
\mathrm{cmol}_{\mathrm{c}} \mathrm{kg}^{-1}\end{array}$ & $\begin{array}{l}\text { Base } \\
\text { saturation } \\
\mathrm{cmol}_{\mathrm{c}} \mathrm{kg}^{-1}\end{array}$ & $\begin{array}{l}\text { Color } \\
\text { (Munsell) }\end{array}$ \\
\hline 1 & $\begin{array}{l}\text { Dystric } \\
\text { Xerochrept }\end{array}$ & $\begin{array}{l}\text { Almendros } \\
\text { et al., } 1990\end{array}$ & $\begin{array}{l}\text { Quercus } \\
\text { rotundifolia }\end{array}$ & 4.8 & 1.4 & 16 & 10 & 2.9 & 10YR6/4 \\
\hline $1^{\prime}$ & (burned) & & & 6.2 & 1.5 & 12 & 18 & 5.5 & $10 \mathrm{YR} 3 / 3$ \\
\hline 2 & $\begin{array}{l}\text { Dystric } \\
\text { Xerochrept }\end{array}$ & $\begin{array}{l}\text { Almendros } \\
\text { et al., } 1988\end{array}$ & Pinus pinea & 5.7 & 3.0 & 12 & 24.6 & 14.3 & $5 Y R \quad 6 / 3$ \\
\hline $2^{\prime}$ & (burned) & & & 6.7 & 4.0 & 11 & 40.2 & 29.2 & 10YR $5 / 1$ \\
\hline 3 & $\begin{array}{l}\text { Calcaric } \\
\text { Cambisol }\end{array}$ & $\begin{array}{l}\text { Tinoco, } \\
2000\end{array}$ & $\begin{array}{l}\text { Pinus } \\
\text { halepensis }\end{array}$ & 6.9 & 21.3 & 14.5 & 70.6 & 49.7 & $10 \mathrm{YR} 3 / 4$ \\
\hline $3^{\prime}$ & (burned) & & & 8.7 & 3.9 & 12 & 13.5 & 13.5 & 10YR $3 / 1$ \\
\hline 4 & $\begin{array}{l}\text { Umbrihumic } \\
\text { Umbrisol }\end{array}$ & $\begin{array}{l}\text { Tinoco, } \\
2000\end{array}$ & $\begin{array}{l}\text { Pinus } \\
\text { sylvestris }\end{array}$ & 4.6 & 6.9 & 14.5 & 23.5 & 2.14 & $10 \mathrm{YR} 3 / 4$ \\
\hline $4^{\prime}$ & $\begin{array}{l}\text { Epidystric } \\
\text { Cambisol } \\
\text { (burned) }\end{array}$ & & & 5.7 & 6.4 & 8 & 41.2 & 4.0 & $10 \mathrm{YR} 2 / 1$ \\
\hline 5 & $\begin{array}{l}\text { Typic } \\
\text { Xerochrept }\end{array}$ & $\begin{array}{l}\text { González-Vila } \\
\text { et al., } 2002\end{array}$ & Pinus sp. & 6.1 & 3.9 & 18.6 & nd & nd & $10 \mathrm{YR} 3 / 4$ \\
\hline $5^{\prime}$ & (burned) & & & 6.8 & 8.6 & 15.6 & nd & nd & $10 \mathrm{YR} 3 / 2$ \\
\hline 6 & $\begin{array}{l}\text { Dystric } \\
\text { Xerochrept }\end{array}$ & $\begin{array}{l}\text { Almendros } \\
\text { et al., 1984a }\end{array}$ & Pinus pinea & 5.9 & 2.8 & 156 & 28.4 & 16.5 & $5 Y R 6 / 3$ \\
\hline $6^{\prime}$ & (burned) & & & 6.9 & 3.8 & 13 & 42.9 & 26.3 & 10YR 5/1 \\
\hline
\end{tabular}

after fire and associated with leaching of nutrients and fly-ash phenomena in burned soils (Smith and Bowes 1974; Athias-Binche and Saulnier 1986). In many cases, total $\mathrm{C}$ did not decrease suggesting a substantial incorporation of forest necromass. This is observed in all samples but in fires of very high intensity like in samples 3-3'. A massive incorporation to soil humus, not only of ash or shoot, but also of black coal and charred plant material do often occurs. The $\mathrm{C} / \mathrm{N}$ ratios of samples after burning were frequently lower than in the original soils, a phenomenon frequently cited in several types of postfire soils (Viro, 1974; Vega, 1986). No granulometric data are presented here, but the general trend is similar to what is reported in the literature; coarser textures after the passage of fire (Almendros et al.,1984a; Kettering et al., 2000).

The amounts of the principal humus fractions extracted are shown in Table 2. When compared with the control soil samples, most postfire soils had increased amounts of the less transformed humus fractions: free organic matter and inherited humin, whereas the lipid proportion is comparatively lower in soils affected by fire.

Amongst the samples studied, again the pair 3-3' represents an extreme situation of high-intensity fire on soil caused by the burnt of a thick and dry pine litter. In 
Table 2. Distribution of different humus fractions in fire affected and not affected soils $\left(\mathrm{C} \mathrm{g} 100 \mathrm{~g} \mathrm{soil}^{-1}\right)$.

\begin{tabular}{|c|c|c|c|c|c|c|c|c|c|c|}
\hline Ref. & Soil & $\begin{array}{l}\text { Total } \\
\text { lipid }\end{array}$ & $\begin{array}{l}\text { Free } \\
\text { organic } \\
\text { matter }\end{array}$ & $\begin{array}{l}\text { Inherited } \\
\text { humin }\end{array}$ & $\begin{array}{l}\text { Total } \\
\text { humic } \\
\text { extract }\end{array}$ & $\begin{array}{l}\text { Humic } \\
\text { acid } \\
\text { (HA) }\end{array}$ & $\begin{array}{l}\text { Fulvic } \\
\text { acid } \\
\text { (FA) }\end{array}$ & HA/FA & $\begin{array}{l}\text { Insolubilized } \\
\text { extractable } \\
\text { humin }\end{array}$ & $\begin{array}{l}\text { Non- } \\
\text { extractable } \\
\text { humin }\end{array}$ \\
\hline 1 & $\begin{array}{l}\text { Dystric } \\
\text { Xerochrept }\end{array}$ & 0.10 & 0.18 & 0.06 & 0.41 & 0.16 & 0.25 & 0.64 & 0.05 & 0.57 \\
\hline $1^{\prime}$ & (burned) & 0.05 & 0.56 & 0.13 & 0.32 & 0.11 & 0.21 & 0.52 & 0.05 & 0.34 \\
\hline 2 & $\begin{array}{l}\text { Dystric } \\
\text { Xerochrept }\end{array}$ & 0.03 & 1.94 & 0.10 & 0.42 & 0.20 & 0.22 & 0.91 & 0.15 & 0.38 \\
\hline $2^{\prime}$ & (burned) & 0.20 & 2.34 & 0.23 & 0.78 & 0.55 & 0.23 & 2.39 & 0.21 & 0.22 \\
\hline 3 & $\begin{array}{l}\text { Calcaric } \\
\text { Cambisol }\end{array}$ & 0.14 & 19.88 & 0.32 & 0.17 & 0.08 & 0.09 & 0.89 & 0.01 & 0.80 \\
\hline $3^{\prime}$ & (burned) & 0.00 & 3.15 & 0.10 & 0.42 & 0.29 & 0.13 & 2.23 & 0.03 & 0.22 \\
\hline 4 & $\begin{array}{l}\text { Umbri- } \\
\text { humic } \\
\text { Umbrisol }\end{array}$ & 0.01 & 3.39 & 0.55 & 2.39 & 1.41 & 0.98 & 1.44 & 0.14 & 0.39 \\
\hline $4^{\prime}$ & $\begin{array}{l}\text { Epidystric } \\
\text { Cambisol } \\
\text { (burned) }\end{array}$ & 0.00 & 5.63 & 0.19 & 0.44 & 0.28 & 0.16 & 1.75 & 0.02 & 0.21 \\
\hline 6 & $\begin{array}{l}\text { Dystric } \\
\text { Xerochrept }\end{array}$ & 0.04 & 1.84 & 0.21 & 0.39 & 0.18 & 0.21 & 0.86 & 0.16 & 0.16 \\
\hline $6^{\prime}$ & (burned) & 0.22 & 2.04 & 0.48 & 0.66 & 0.45 & 0.21 & 2.14 & 0.29 & 0.19 \\
\hline
\end{tabular}

this situation, high temperatures on soil surface occurs destroying particulate soil organic fractions.

\subsubsection{Effect of fires on soil respiratory activity}

One example of the in vitro respiratory activity of soil samples under laboratory conditions is shown in Figure 1 . The results clearly show a decrease in the $\mathrm{C}$ mineralization rate, suggesting a decrease in the SOM's biodegradability. This situation is frequent in pine forests, where the high combustibility of the resinous plants and residues, more or less totally destroyed during a forest fire, led to the accumulation of black carbon and other organic materials highly refractory to biodegradation.

The above results found for a pine forests are different to those obtained in oak forest under similar geomorphological and climatic conditions (Almendros et al., 1990). In the oak soil (soil 1-1') there where not large differences and, during the first incubation period ( 0 to 20 days) the activity in the postfire soil sample increased, suggesting a rapid microbial recolonization of the burnt soil, presumably enriched with the incorporation of readily biodegradable plant material and an enrichment of exchangeable cations as previously described. After the 30 th day of incubation, the differences were lower although the activity in the control soil sample became slightly higher than in that from the burned area. 

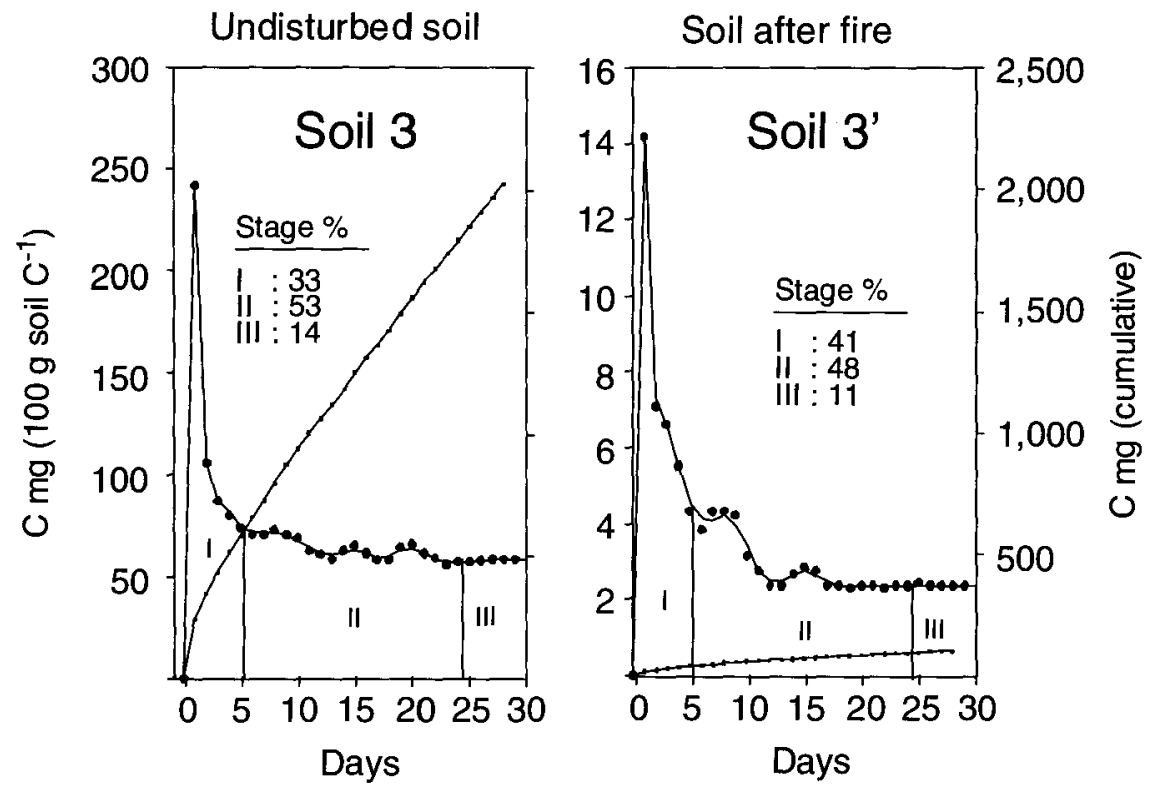

Figure 1. Carbon dioxide production in undisturbed and affected by a severe fire soils.

\subsubsection{Influence of fires on lipid composition}

In general the greatest differences in lipid composition among soils affected and unaffected by fire were these found in the distribution patterns of alkyl compounds (alkanes, fatty acids). In particular, the low molecular weight $\left(<\mathrm{C}_{20}\right)$ homologues were dominant in the burnt soils, also the resin acids are more abundant with the higher values for the dehydroabietic and secodehydroabietic acids and the lowest ones for pimaric acid.

In the burnt soil, the lipid fraction was more than six times greater in weight than in the control sample. This difference is attributed to the translocation into the soil of organic substances released from burning litter or biomass (De Bano et al., 1970, 1976). The formation of non-wettable soils after forest fires have been considered to be partially due to the occurrence of similar phenomena (Savage, 1974; Giovannini and Luchessi, 1984). Major constituents of the hydrocarbon fraction were $\mathrm{C}_{14}$ to $\mathrm{C}_{33} n$-alkanes, some branched alkanes, and dehydroabietin. The latter hydrocarbon (in relation to alkanes) was found to be very resistant to burning in laboratory controlled experiments (Almendros et al., 1988). A similar resistance was observed for the branched alkanes, the relative proportions of which did not differ significantly in the studied conditions (Figure 2).

Important differences were detected in the distribution patterns of $n$-alkanes (Figure 3 ). The control soil sample showed a bimodal distribution with a maximum of $\mathrm{C}_{29}$ and a predominance of the odd-C numbered chains (even/odd ratio $=0.6$ ), which suggests a significant input of cuticular waxes from higher plants to the soil lipid fraction (Simoneit and Mazurek, 1982). In the sample from the post-fire site, there 

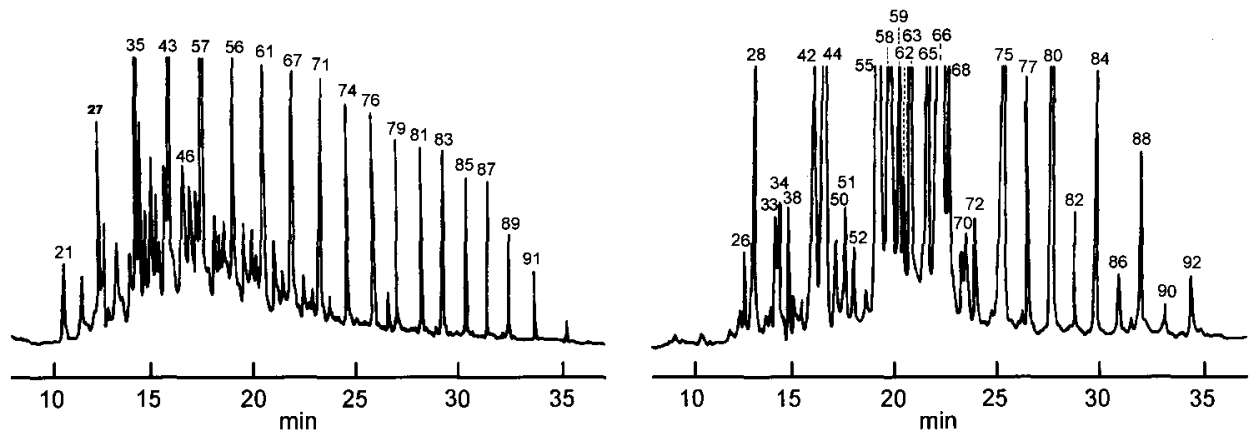

Figure 2. Gas chromatographic separation of the soil lipids fractions from a Dystric Xerochrept after a forest fire: Alkane (left) and acid fraction (resin and fatty acids, right). Compound numbers refer to Table 3.

were higher amounts of alkanes with lower molecular weight $\left(<\mathrm{C}_{25}\right)$ and no predominance of the odd- $\mathrm{C}$ numbered chains, the maximum was found for the $\mathrm{C}_{18}-$ $\mathrm{C}_{20}$ region (total even/odd ratio $=0.8$ ).

The differences observed in the more polar lipid fraction (fatty acids and resin acids) were also important (Figure 3). In the case of the control sample the fatty
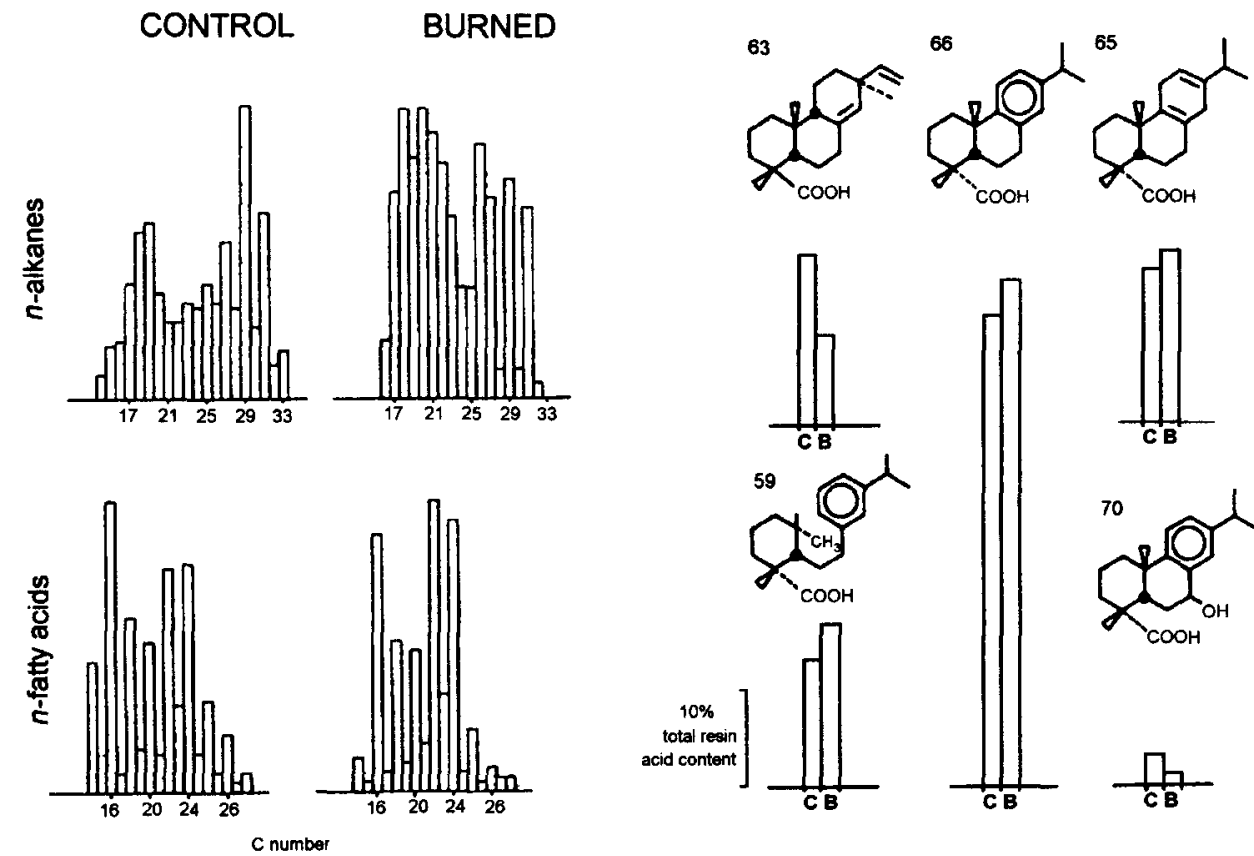

Figure 3. Influence of a forest fire in the distribution diagrams (relative abundance $v s$. C number) of $n$ alkanes and $n$-fatty acids (left) and in the relative proportion or resin acids (right) in a pine forest soil. The compound numbers refer to Table 3 . 
Table 3. Organic compounds in soil lipid fractions and in degradation products of humic substances (as methyl esters, Roman numbers indicate different isomers).

\begin{tabular}{|c|c|c|}
\hline \multicolumn{2}{|c|}{ No.Compound } & No.Compound \\
\hline 1 & Dimethyl glutarate & $47 n$-Eicosane \\
\hline 2 & Methoxybenzenecarboxylic acid methyl ester (I) & 48 Methoxybenzenetricarboxylic acid trimethyl ester (II) \\
\hline 3 & Methyl 3-phenyl propionate & 49 17-C unsaturated fatty acid methyl ester \\
\hline 4 & Methoxybenzenecarboxylic acid methyl ester (II) & 50 17-C Branched fatty acid methyl ester (I) \\
\hline 5 & Dimethyl pimelate & 51 17-C Branched fatty acid methyl ester (II) \\
\hline 6 & Methoxybenzenecarboxylic acid methyl ester (III) & 52 Methyl heptadecanoate \\
\hline 7 & Propanetricarboxylic acid trimethyl ester & 53 Dimethyl tetradecanedioate \\
\hline 8 & $n$-Tetradecane & 54 1,2,3,4-Benzenetetracarboxylic acid tetramethyl ester \\
\hline 9 & 1,2-Benzene dicarboxylic acid dimethyl ester & 55 Methyl octadecenoate \\
\hline 10 & Dimethoxybenzaldehyde & $56 n$-Heneicosane \\
\hline 11 & 8-C Branched alkanoic diacid dimethyl ester & 57 1,2,4,5-Benzenetetracarboxylic acid tetramethyl ester \\
\hline 12 & Dimethyl suberate & 58 Methyl octadecanoate \\
\hline 13 & $\begin{array}{l}\text { 1,3-Benzenedicarboxylic acid dimethyl } \\
\text { ester }\end{array}$ & $\begin{array}{l}59 \text { Methyl } 2 S \text {-(2' ( } m \text {-isopropylphenyl)ethyl)- } 1 R, 3 S- \\
\text { dimethylcylohexanecarboxylate }\end{array}$ \\
\hline 14 & 1,4-Benzenedicarboxylic acid dimethyl ester & 60 1,2,3,5-Benzenetetracarboxylic acid tetramethyl ester \\
\hline 15 & $n$-Pentadecane & $61 n$-Docosane \\
\hline 16 & Paratoluenesulphonic acid methyl ester & 62 Methyl nonadecanoate \\
\hline 17 & 9-C Branched alkanoic diacid dimethyl ester & 63 Methyl-8(14),15-pimaradien-18-oate \\
\hline 18 & Methyl dodecanoate & 64 Dimethyl hexadecanedioate \\
\hline 19 & Dimethyl azelate & 65 Methyl 8,12-abietadien-18-oate \\
\hline 20 & Dimethoxybenzenecarboxylic acid dimethyl ester & 66 Methyl 8,11,13-abietatrien-18-oate \\
\hline 21 & $n$-Hexadecane & $67 n$-Tricosane \\
\hline 22 & 10-C Branched alkanoic diacid dimethyl ester & 68 Methyl eicosanoate \\
\hline 23 & Dimethyl decanedioate & 69 Dioctyl adipate \\
\hline 24 & Methoxybenzenedicarboxylic acid dimethyl ester (I) & 70 Methyl 7-hydroxydehydroabietate \\
\hline 25 & Methyl $p$-methoxycinnamate & $71 n$-Tetracosane \\
\hline 26 & 14-C unsaturated fatty acid methyl ester & 72 Methyl heneicosanoate \\
\hline 27 & $n$-Heptadecane & 73 Dimethyl octadecanedioate \\
\hline 28 & Methyl tetradecanoate & $74 n$-Pentacosane \\
\hline 29 & 11-C Branched alkanoic diacid dimethyl ester & 75 Methyl docosanoate \\
\hline 30 & Dimethyl undecanedioate & $76 n$-Hexacosane \\
\hline 31 & Methoxybenzenedicarboxylic acid dimethyl ester (II) & 77 Methyl tricosanoate \\
\hline 32 & 1,2,3-Benzenetricarboxylic acid trimethyl ester & 78 Branched alkane \\
\hline 33 & 15-C Branched fatty acid methyl ester (I) & $79 n$-Heptacosane \\
\hline 34 & 15-C Branched fatty acid methyl ester (II) & 80 Methyl tetracosanoate \\
\hline 35 & $n$-Octadecane & 81 -Octacosane \\
\hline 36 & 1,2,4-Benzenetricarboxylic acid trimethyl ester & 82 Methyl pentacosanoate \\
\hline 37 & 12-C Branched alkanoic diacid dimethyl ester & $83 n$-Nonacosane \\
\hline 38 & Methyl pentadecanoate & 84 Methyl hexacosanoate \\
\hline 39 & Branched alkane & $85 n$-Triacontane \\
\hline 40 & $o$-Terphenyl & 86 Methyl heptacosanoate \\
\hline 41 & Benzene tricarboxylic acid trimethyl ester & $87 n$-Hentriacontane \\
\hline & Methyl hexadecenoate & 88 Methyl octacosanoate \\
\hline 43 & $n$-Nonadecane & $89 n$-Dotriacontane \\
\hline 44 & Methyl hexadecanoate & 90 Methyl nonacosanoate \\
\hline & Methoxybenzenetricarboxylic acid trimethyl ester (I) & $91 n$-Tritriacontane \\
\hline 46 & 18-Norabieta-8,11,13-triene & 92 Methyl triacosanoate \\
\hline
\end{tabular}


acids ranged from $\mathrm{C}_{14}$ to $\mathrm{C}_{30}$ : the maximum was found in the $\mathrm{C}_{16}$ acid, but the relative proportion of the longer-chain acids $\left(>C_{20}\right)$ was important, also confirming a considerable contribution from waxes of higher plants origin to the soil lipids. In the case of sample after burning, the total proportion of long-chain acids was similar to that of the control sample, but higher in individual cases $\left(\mathrm{C}_{22}\right.$ and $\left.\mathrm{C}_{24}\right)$.

Among the conifer resin compounds identified (Zinkel et al., 1971), the most abundant were the dehydroabietic acid (comp. No. 66, Table3); pimaric acid (No. 63), one abietadienoic acid (No. 65) and one hydroxydehydroabietic acid (secodehydroabietic acid, No. 70; Ekman, 1979). An unusual resin acid (comp. No. 59) was also found in all the samples (Takeda et al., 1968; Zinkel et al., 1969). Terphenyl (No. 40) appeared only in fire affected soil. The pimaric acid showed the lowest resistance to burning. The amount of dehydroabietic acid increased relatively under laboratory heating, perhaps as a consequence of transformations of the other resin acids, as described for the natural diagenetic pathways in this kind of compounds (Simoneit and Mazurek, 1982). On the other hand, the important quantity of secodehydroabietic acid observed in the samples after burning, might be partially due to a thermal ring opening of other resin acids (Takeda et al., 1968).

\subsubsection{Nature of the refractory organic $C$ forms in soils affected by wildfires} as inferred by flash pyrolysis and solid-state ${ }^{13} \mathrm{C}-N M R$ analyses

It is believed that, in well-aerated tropical environments, only a fraction of the total production of refractory elemental $\mathrm{C}$ (charcoal, charred material, black carbon) from biomass burning is likely to be sequestered in the slow-cycling soil $\mathrm{C}$ reservoir (Bird et al., 1999). However, in Continental Mediterranean regions, where extreme climatic conditions alternate along the year, abiotic constrains such as wildfires and intense dehydration may favor the formation of stable SOM forms. The nature of this refractory $\mathrm{C}$ can be approached by using analytical techniques that allows the study of SOM at a molecular level from whole soil samples, such as flash pyrolysis and solid-state ${ }^{13} \mathrm{C}-\mathrm{NMR}$.

Figure 4 shows the changes in the pyrolytic patterns of raw forest soil samples before (control) and after being affected by wildfires (burnt). The numbers on the peaks corresponds to the pyrolysis compounds listed in Table 4. Upon pyrolysis, the control soils release a wide variety of anhydrosugar and furan compounds as well as $\mathrm{N}$-containing products, arising respectively from carbohydrate and peptidic domains. In addition, lignin-derived methoxyphenols with both guaiacyl and syringyl skeletons, as well as alkyl molecules from lipid material are clearly identified. On the contrary, in the forest soils affected by wildfire, most pyrolysis products that were present in the control soils vanishes and the dominance of charred "non pyrolyzable" refractory carbonaceous material is evident (Figure 4 and Table 4).

The formation of condensed refractory materials after forest fire is again evident in the solid-state ${ }^{13} \mathrm{C}$-NMR spectra from the same sample. A representative case (Pinus halepensis forest) is shown in Figure 5, which includes a Table with the distribution and tentative assignments of the different $\mathrm{C}$-types. In general, a neat increase in the intensity of the aromatic $C$ region $(160$ to $110 \mathrm{ppm})$ is observed, dominance which occurs at the expenses of the $O$ - and $N$-alkyl C region (110 to 60 


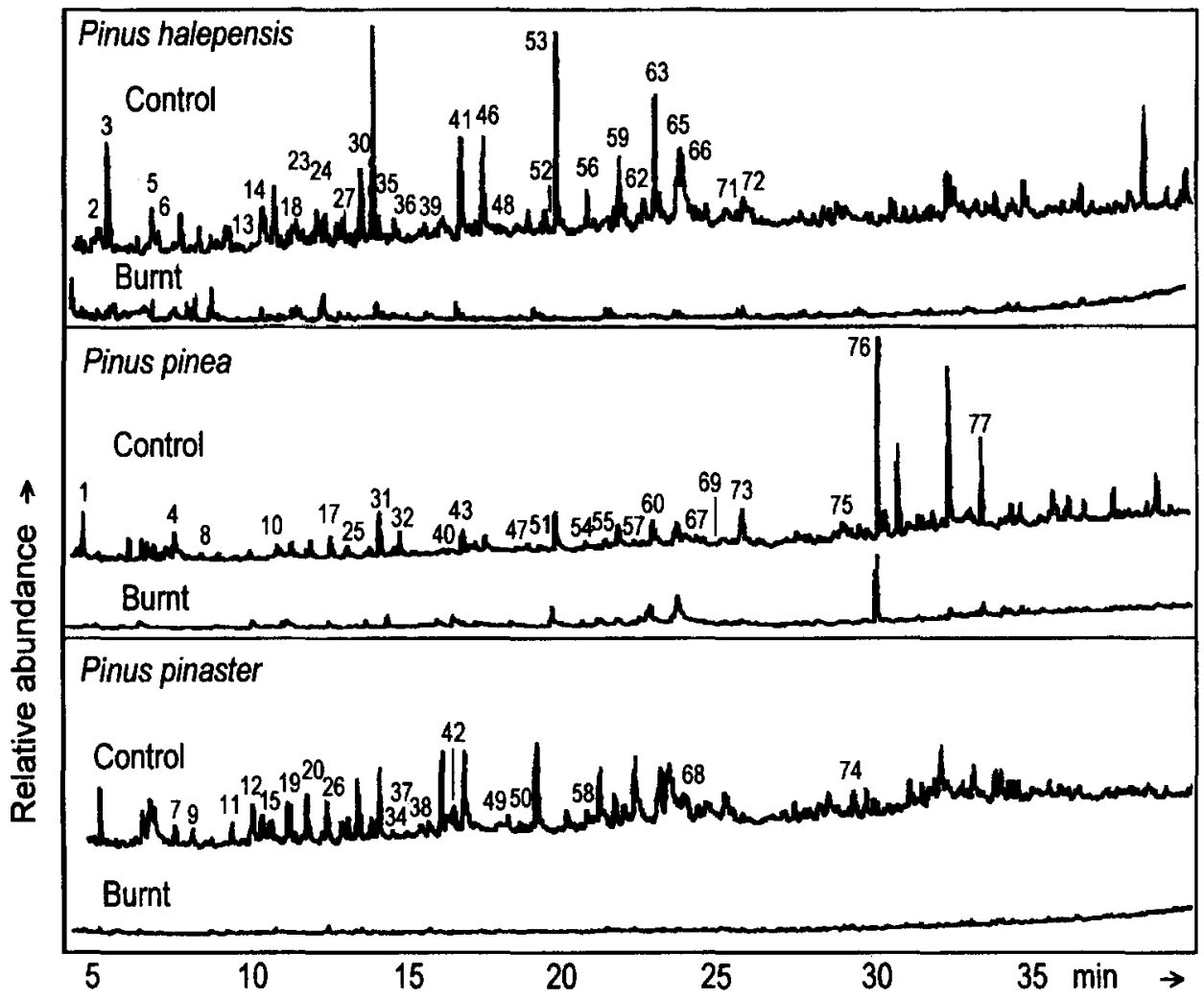

Figure 4. Changes in the pyrolytic patterns of raw soil samples from different pine forests formations unaffected (control) and affected (burnt) by wildfires.

$\mathrm{ppm}$ ), as it is evident from the integration values of the different $\mathrm{C}$ regions. This indicates that the increase in C observed in the fire-affected soil is mainly due to the soil enrichment in charred material rather than to inputs of fresh litter after the fire. This is further corroborated when analysing the NMR ratio $(160 / 110 \mathrm{ppm}) /(110 / 45 \mathrm{ppm})$, that is $<1$ in all particle fractions of the unaffected soil and $>1$ in all particle fractions of the fire-affected one. Another indicator of SOM condensation and the formation of refractory, polyaromatic and relatively inert $\mathrm{C}$ forms (black carbon-like), is that the $O$-alkyl C/alkyl C ratio in the fire-affected soil is always lower than in the original soil.

\subsection{Laboratory simulation experiments}

\subsubsection{Whole soils}

The data in Table 5 confirm the tendencies found in previous analyses on naturallyheated soils; a progressive increase in soil $\mathrm{pH}$, the relative stability of the $\mathrm{C} / \mathrm{N}$ ratio (only decreasing after severe heating) and the destruction (probably due to irreversible aggregation) of the clay soil fraction. 
Table 4. Pyrolysis compounds identified by GC/MS in the control soils.

\begin{tabular}{|c|c|c|c|}
\hline 1 & Benzene & 40 & Catechol \\
\hline 2 & 2-Methyl-2-cyclopentene-1-one & 41 & 2-Acetoxy-5-ethylfuran \\
\hline 3 & Toluene & 42 & 3,5-Dihydroxy-2-methyl-(4H)-pyran-4-one \\
\hline 4 & Furfural & 43 & Methylguaiacol \\
\hline 5 & 1H-pyrrole, 3-methyl & 44 & 5-Hydroxyl-2-furfuraldehyde \\
\hline 6 & 2-Hydroxymethylfuran & 45 & Methoxymethylbenzene \\
\hline 7 & Styrene & 46 & 4-Vinylphenol \\
\hline 8 & Cyclopente-1-ene-3,4-dione & 47 & 4-Methylcatechol \\
\hline 9 & 2-Methyl-2-cyclopente-1-one & 48 & 4-Ethyl-2-methylphenol \\
\hline 10 & 2-Acetylfuran & 49 & 4-Ethylguaiacol \\
\hline 11 & 2,3-Dihydro-5-methylfuran-2-one & 50 & 4-Hydroxybenzyl alcohol \\
\hline 12 & 5-Methyl-2-furfuraldehyde & 51 & Indole \\
\hline 13 & Benzylalcohol & 52 & 1,4-Dideoxy-D-glycerohex-1-enopyranos-3-ulose \\
\hline 14 & Benzaldehyde & 53 & Vinylguaiacol \\
\hline 15 & Phenol & 54 & trans-Propenylphenol \\
\hline 16 & 5-Methyl-2-furfuraldehyde & 55 & 2,6-Dimethoxyphenol \\
\hline 17 & 4-Hydroxy-5,6-dihydro- $(2 H)$-pyran-2-one & 56 & Eugenol \\
\hline 18 & 5,6-Dihydropyran-2,5-dione & 57 & 4-Propylguaiacol \\
\hline 19 & 3-Hydroxy-2-methyl-2-cyclopenten-1-one & 58 & 3-Methylindole \\
\hline 20 & 2,4-Dihydropyran-3-one & 59 & Vanillin \\
\hline 21 & 2-Methoxy toluene & 60 & $c i s$-Isoeugenol \\
\hline 22 & 2-Hydroxy-3-methyl-2-cyclopenten-1-one & 61 & 4-Hydroxyacetophenone \\
\hline 23 & 4-Isopropyltoluene & 62 & Homovanillin \\
\hline 24 & 2,3-Dimethylcyclopenten-1-one & 63 & trans-Isoeugenol \\
\hline 25 & Hydroxymethyldihydropyranone & 64 & 1-(4-Hydroxy-3-methoxyphenyl) \\
\hline 26 & 5-Ethyl-2-furfural & 65 & Acetovanillone \\
\hline 27 & $o$-Cresol & 66 & Vanillic acid methyl ester \\
\hline 28 & 2-Furoic acid methyl ester & 67 & 4-Ethyl-2,6-dimethoxyphenol \\
\hline 29 & 4-Methylphenol, $p$-cresol & 68 & Guaiacylacetone \\
\hline 30 & 2,6-Dimethylphenol & 69 & 2,6-Dimethoxy-4-vinyphenol \\
\hline 31 & Guaiacol & 70 & 1,6-Anhydro- $b$-glucofuranose \\
\hline 32 & Levoglucosenone & 71 & Guaiacylpropan-2-one \\
\hline 33 & 3-Hydroxy-2-methyl-(4H)-pyran-4-one & 72 & Propiovanillone \\
\hline 34 & Dimethyldihydropyranone & 73 & Guaiacyl vinyl-2-one \\
\hline 35 & Phenylacetonitrile & 74 & trans-Coniferaldehyde \\
\hline 36 & 3-Hydroxy-2methyl-(4H)-pyran-4-one & 75 & Retene \\
\hline 37 & 2,4-Dimethylphenol & 76 & Myristic acid \\
\hline 38 & Benzoic acid & 77 & Palmitic acid \\
\hline 39 & 4-Ethylphenol & & \\
\hline
\end{tabular}

The chemical fractionation of the SOM shows the progressive thermal destruction of the different humic fractions. The data referred to soil weight (Table 6) show the rapid decrease in the proportion of all humic fractions when the samples are subjected to the most intense heating (samples III-V). Nevertheless, at low temperatures (samples I-III), it is possible to distinguish between fractions that are relatively resistant to fire effects, with sample III not showing an excessive depletion or even some relative increase in HAs and for all types of humin. The opposite 


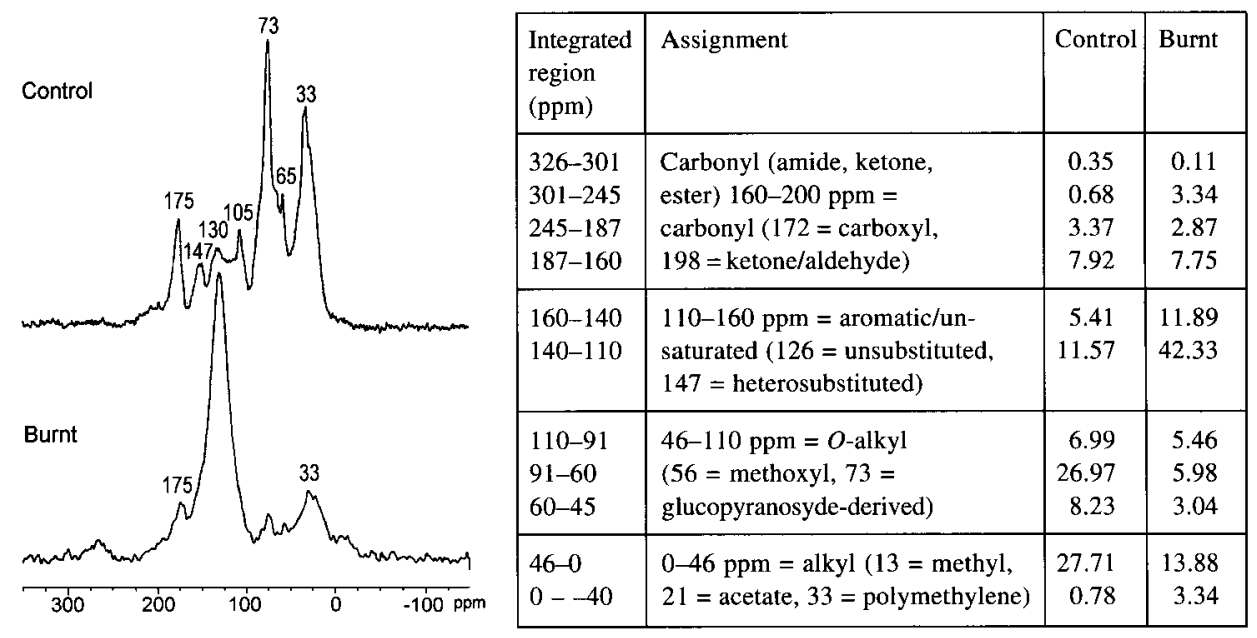

Figure 5. Changes after wildfire on the solid-state ${ }^{13} \mathrm{C}-\mathrm{NMR}$ spectrum of a raw forest soil sample. Distribution of different $\mathrm{C}$ types.

Table 5. General characteristics of whole soil samples subjected to progressive laboratory heating (Dystric Xerochrept under Pinius pinea forest from Almendros et al., 1984b).

\begin{tabular}{|c|c|c|c|c|c|c|}
\hline Soil & $\begin{array}{l}\text { Heating } \\
\text { conditions }\end{array}$ & $\mathrm{pH}$ & $\begin{array}{l}\% \mathrm{C} \\
\mathrm{g} / 100 \mathrm{~g}\end{array}$ & $\mathrm{C} / \mathrm{N}$ & $\begin{array}{l}\text { Clay } \\
\left(\mathrm{g} \cdot 100 \mathrm{~g} \mathrm{soil}{ }^{-1}\right)\end{array}$ & $\begin{array}{l}\text { Color } \\
\text { (Munsell) }\end{array}$ \\
\hline $\begin{array}{ll}0 & \text { (control) Dystric } \\
& \text { Xerochrept }\end{array}$ & Control (no heating) & 5.8 & 2.8 & 15.5 & 5.2 & 5 YR $6 / 3$ \\
\hline I (heated soil) & $1000^{\circ} \mathrm{C}, 20 \mathrm{sec}, \mathrm{T}^{*}=100^{\circ} \mathrm{C}$ & 5.8 & 2.3 & 16.4 & 3.2 & $10 Y R 4 / 3$ \\
\hline II (burned forest) & $1000^{\circ} \mathrm{C}, 40 \mathrm{sec}, \mathrm{T}=100^{\circ} \mathrm{C}$ & 5.9 & 2.2 & 16.8 & 3.0 & $10 Y R 4 / 3$ \\
\hline III (burned forest) & $1000^{\circ} \mathrm{C}, 80 \mathrm{sec}, \mathrm{T}=100^{\circ} \mathrm{C}$ & 6.5 & 2.0 & 14.3 & 2.0 & 10YR $3 / 3$ \\
\hline IV (burned forest) & $1000^{\circ} \mathrm{C}, 160 \mathrm{sec}, \mathrm{T}=100^{\circ} \mathrm{C}$ & 7.9 & 1.5 & 21.4 & 1.9 & $10 \mathrm{YR} 3 / 2$ \\
\hline$V$ (burned forest) & $1000^{\circ} \mathrm{C}, 320 \mathrm{sec}, \mathrm{T}=100^{\circ} \mathrm{C}$ & 9.5 & 0.6 & 31.1 & 1.0 & $10 \mathrm{YR} 3 / 2$ \\
\hline
\end{tabular}

*Final temperature

effect is observed for fractions with a more thermolabile character (free organic matter and FA). In particular, the extractable insolubilised humin (HA and FA-type substances linked to clays and oxides) behaves as the most resistant of the alkalisoluble fractions. In fact, in sample III the amount of this humic fraction increased, a circumstance suggesting that a certain proportion of compounds present in the total humic extract have turned into non-extractable forms due to the high temperatures. This effect is similar to that described for drastic dryings of the soil, that diminish the extractability of the organic matter by the appearance of additional adsorption effects in the clay-humus complex (Greenland, 1971).

When referring the results to the total soil $\mathrm{C}$ (Figure 6), the different thermoestability of the humic fractions became evident, as well as the relative increase in 
Table 6. Organic fractions isolated from soil samples subjected to laboratory heatings $\left(\mathrm{C} \mathrm{g} \cdot 100 \mathrm{~g}\right.$ soil $\left.{ }^{-1}\right)$.

\begin{tabular}{|c|c|c|c|c|c|c|c|c|}
\hline Soil & $\begin{array}{l}\text { Free } \\
\text { organic } \\
\text { matter }\end{array}$ & $\begin{array}{l}\text { Inherited } \\
\text { humin }\end{array}$ & $\begin{array}{l}\text { Total } \\
\text { humic } \\
\text { extract }\end{array}$ & $\begin{array}{l}\text { Humic } \\
\text { acid } \\
\text { (HA) }\end{array}$ & $\begin{array}{l}\text { Fulvic } \\
\text { acid } \\
\text { (FA) }\end{array}$ & HA/FA & $\begin{array}{l}\text { Insolubilised } \\
\text { extractable } \\
\text { humin }\end{array}$ & $\begin{array}{l}\text { Non- } \\
\text { extractable } \\
\text { humin }\end{array}$ \\
\hline Dystric Xerochrept & 1.84 & 0.21 & 0.39 & 0.18 & 0.21 & 0.86 & 0.16 & 0.20 \\
\hline I (heated soil) & 1.21 & 0.19 & 0.38 & 0.17 & 0.21 & 0.81 & 0.14 & 0.38 \\
\hline II (burned forest) & 1.00 & 0.21 & 0.31 & 0.17 & 0.14 & 1.21 & 0.16 & 0.50 \\
\hline III (burned forest) & 0.90 & 0.16 & 0.17 & 0.09 & 0.08 & 1.13 & 0.24 & 0.53 \\
\hline IV (burned forest) & 0.58 & 0.10 & 0.06 & 0.02 & 0.04 & 0.50 & 0.11 & 0.65 \\
\hline$V$ (burned forest) & 0.20 & 0.03 & 0.03 & 0.01 & 0.02 & 0.50 & 0.01 & 0.36 \\
\hline
\end{tabular}

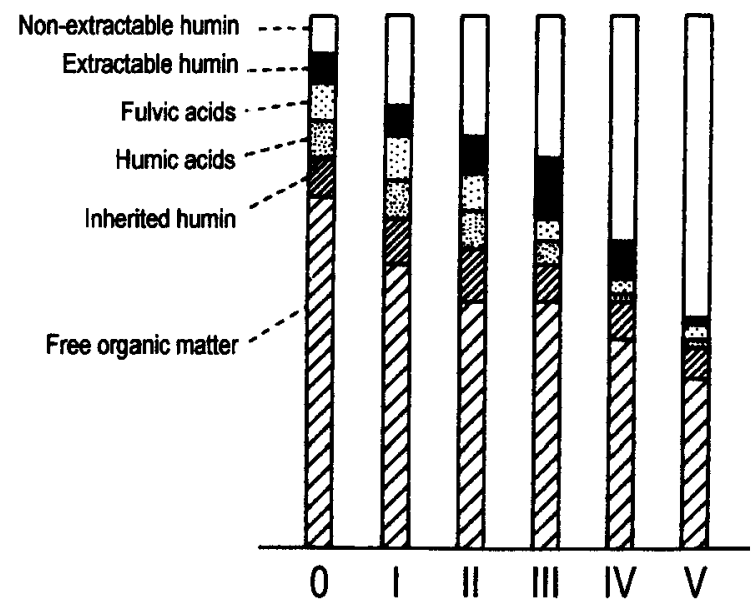

Figure 6. Effect of progressive heating on soil humus fractions from a Dystric Xerochrept soil under Pinus pinea forest. Sample 0 to V. Refer to Tables 5 and 6.

the content of HA and humin in the less transformed samples. The progressive increase in the non-extractable humin fraction would correspond to the accumulation of black carbon.

\subsubsection{The effects of heating on isolated humus fractions (HAs and FAs)}

3.2.1.1. Influence on the bulk humus characteristics. The results obtained during laboratory experiment using a mineral soil mixed with pure humic fractions (Almendros et al., 1990) are shown in Figure 7. Data is expressed as percentages of the final weight.

The maximum loss of weight observed was about $50 \%$ for the HA and more than $60 \%$ for the FA when heated at $350{ }^{\circ} \mathrm{C}$ for 150 seconds.

Outstanding transformation is observed in the heated HAs and FAs with a drastic change in solubility properties. In a first stage, half the HA was transformed into 
HUMIC ACID

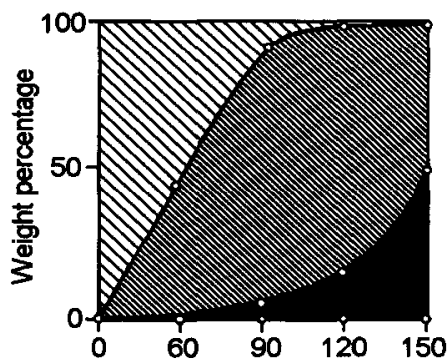

FULVIC ACID

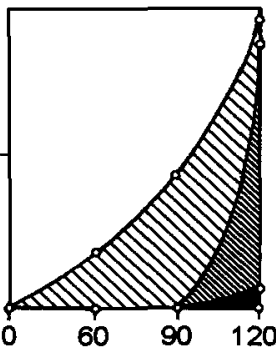

120 $\square$ Fulvic acid-like

Humic acid-like

Humin-like

Black carbon

Oxidation time at $350^{\circ} \mathrm{C}$

Figure 7. Progressive transformation of humic acid fulvic acids into mixtures of humic-like macromolecular fractions in laboratory-controlled conditions.

an alkali-insoluble macromolecular material, and that insolubility drastically increased with the subsequent thermal stages. This transformation was also noteworthy in the FA case, which is first transformed into an acid-insoluble macromolecule (HA-like) and then into an alkali-insoluble substance (humin-like). In addition, after alkaline permanganate oxidation of both humic fractions, we found a variable amount of unoxidized residue. After examining these residues by IR spectroscopy and elementary analysis, our findings were consistent with these of black carbon, the relative abundance of this material is that presented in Figure 7.

The above changes in solubility are in relation with changes observed in the elementary analysis of the HAs and FAs. When the atomic $\mathrm{H} / \mathrm{C}$ and $\mathrm{O} / \mathrm{C}$ ratios are presented in a van Krevelen (1950) diagram (Figure 8), it is observed that fire lead

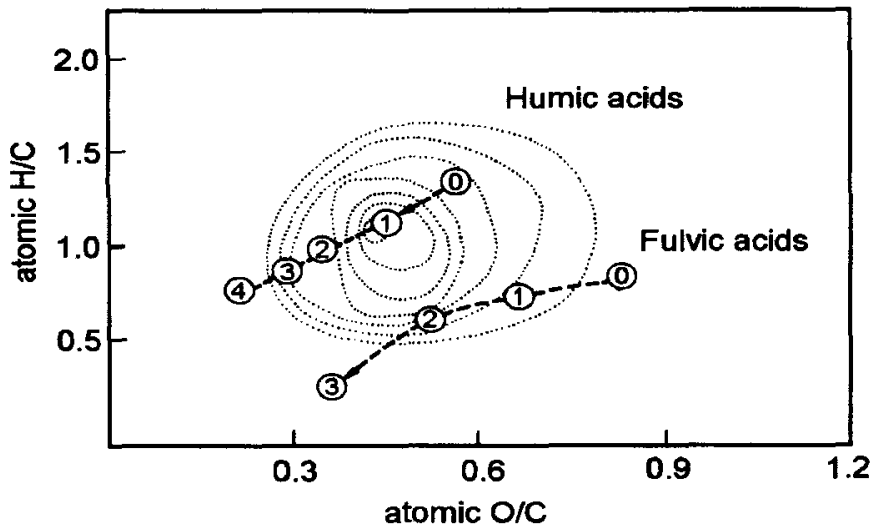

Figure 8. Changes in the elementary composition of HA and FA in the laboratory-controlled heating at $350{ }^{\circ} \mathrm{C}$ for 0 to 150 seconds (encircled numbers 0 to 4 ). The kinetics are superimposed in a contour diagram showing natural variability in the distribution and frequencies of the atomic $\mathrm{H} / \mathrm{C}$ and $\mathrm{O} / \mathrm{C}$ ratios in HAs. 
to an important decrease in the atomic $\mathrm{H} / \mathrm{C}$ ratio suggesting an increase in aromaticity and a decrease in the atomic $\mathrm{O} / \mathrm{C}$ ratio. A substantial lose of oxygen-containing functional groups do occur, which could explain the progressive alteration in the colloidal properties of the soil.

These changes (simultaneous dehydration and decarboxylation) were found both after natural and laboratory burnings (Almendros et al., 1990) and are in agreement with the behavior of humic substances during thermal treatments (Schnitzer and Khan, 1972). The points represented in Figure 8 are plotted on a contour map for the natural variability of atomic $\mathrm{H} / \mathrm{C}$ and $\mathrm{O} / \mathrm{C}$ ratios of $273 \mathrm{HAs}$ from different types of soil, determined in our laboratories and used to compare with the composition of terrestrial HAs.

The transformation paths of the atomic ratios of FAs are included within the variability limits of the elementary composition of soil HAs (1 and 2), finally to reach - as the HA path - a composition that could be ascribed to that of humin and black carbon. It is probable that irreversible dehydration and decarboxylation of the humic colloids may play an important role in the fire-induced water-repellence of soils after burning. In fact, the water drop penetration time (WDPT, Savage et al., 1972) of the HA sample from the unaltered site $(0)$ was estimated to be lower than $1 \mathrm{~s}$, whereas this period was $32 \mathrm{~s}$ in the soil sample after natural burning (Almendros et al., 1990). This difference is noteworthy after considering that the free lipid fraction in this soil (1-1', Table 1) was much lower in the latter sample than in the former control sample (Table 2).

Several studies (De Bano et al. 1970, 1977; Savage et al. 1972) have shown that the fire-induced translocation and fixation of hydrophobic compounds could be responsible for the formation of water-repellent soil horizons, but our results suggest that the changes in the surface properties of the humus substances may also greatly increase the hydrophobicity of soils after burning. In fact, it can easily be checked that the laboratory-heated humic substances ( 1 to 4 ) became slowly wettable after heating. The thermal loss of the oxygen-containing functional groups turn the surface of the humic macromolecules hydrophobic and the peripheral rearrangement of the heat-surviving polymethylene constituents (Almendros et al., 1988) may contribute to this, as well as the fixation of additional lipid material to the HAs as discussed below.

It appears that $\mathrm{N}$, is present in very stable forms since the $\mathrm{C} / \mathrm{N}$ ratio of the HAs was surprisingly constant during the whole experiment (ca. 12), indicating relative losses of $\mathrm{N}$ and $\mathrm{C}$ similar in the more extreme treatment (sample $4=37 \% \mathrm{C}$ and $35 \%$ $\mathrm{N}$ ). This stability of $\mathrm{N}$ can partially explain the increase in the $\mathrm{N}$ content classically found in several postfire soils and could be partially attributed to the formation of very stable $\mathrm{N}$ forms during the thermal diagenesis of the HA-type macromolecules (Almendros et al., 1984a). However, the $\mathrm{N}$ compounds in the FA studied here did not present the above resistance to thermal effects, with losses up to $73 \%$.

3.2.1.2. Assessment of changes by spectroscopic techniques. The IR spectroscopy revealed additional details on the effect of heating (Almendros et al., 1992). In Figure 9, raw IR spectra are compared with the resolution-enhanced IR spectra. The 

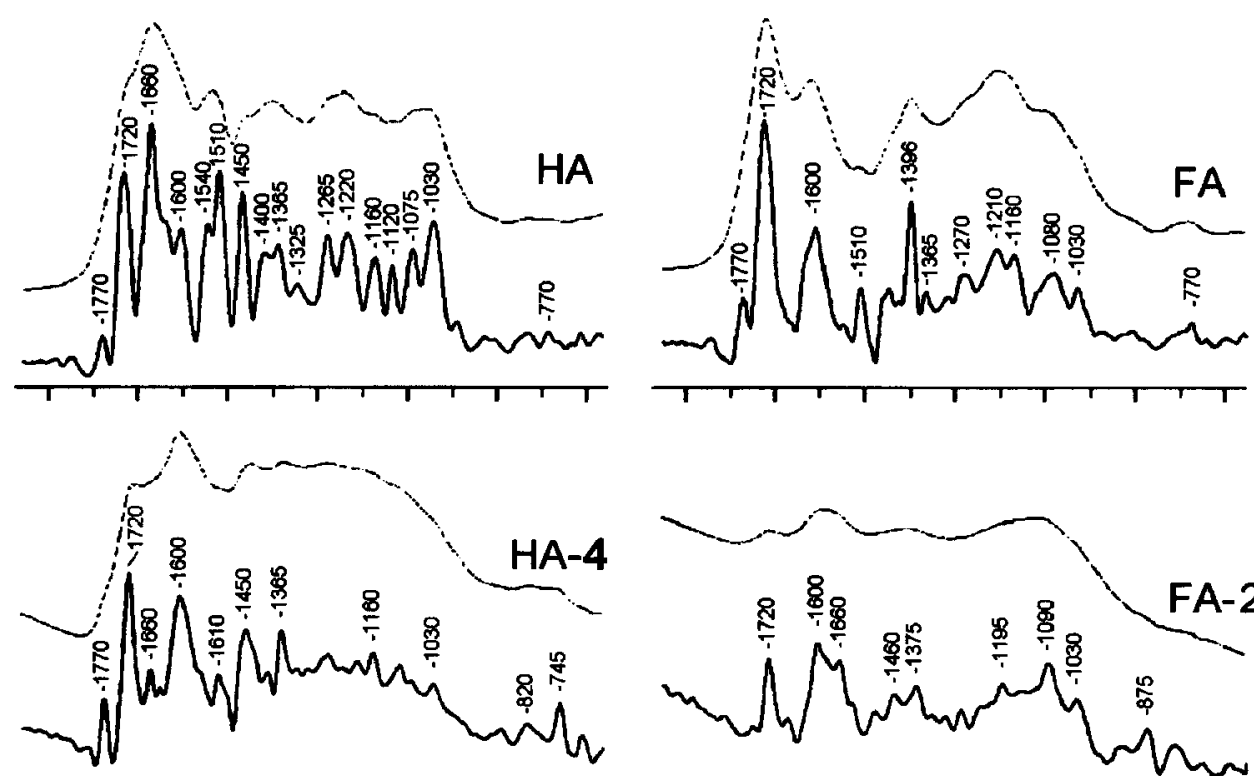

$19001700150013001100900 \mathrm{~cm}^{\prime}-1$

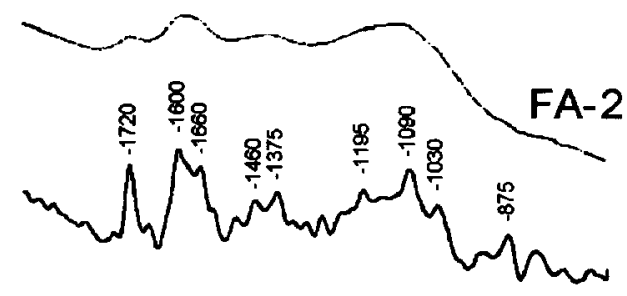

$190017001500130011000^{\prime} 900{ }^{\prime} \mathrm{cm}^{\prime}{ }^{\prime}$

Figure 9. Resolution-enhanced infrared spectra (continuous line) and original spectrum (dashed line) of unheated humic acids (HA) and fulvic acids (FA) and the same samples subjected to laboratory heating at $350^{\circ} \mathrm{C}$ for 150 seconds (HA-4) or $90 \mathrm{sec}$ (FA-2) (soil samples $1-1^{\prime}$ as described in Table 1).

control unheated HA spectrum displayed a pattern that resembled at first sight that of a lignin preparation: in addition to the aromatic ring vibrations at $1600 \mathrm{~cm}^{-1}$ and $1510 \mathrm{~cm}^{-1}$ there was a series of diagnostic peaks at 1450, 1400, 1365, 1325, 1265 , 1220 and $1030 \mathrm{~cm}^{-1}$ (Fengel and Wegener, 1984). The peaks at $1660 \mathrm{~cm}^{-1}$ and 1540 $\mathrm{cm}^{-1}$ corresponded to amide bands, and the carboxyl groups can be mainly responsible for the bands at around $1720 \mathrm{~cm}^{-1}, 1400 \mathrm{~cm}^{-1}$ and at $770 \mathrm{~cm}^{-1}$ (carboxyl rocking). The $\mathrm{C}-\mathrm{O}$ vibration at $1770 \mathrm{~cm}^{-1}$ may be due to $\mathrm{O}$-containing heterocyclic rings as cyclic anhydrides, which can be formed by heat treatment (Wright and Schnitzer, 1961).

After laboratory heating (HA-4), the above lignin pattern disappeared, as well as the amide bands. The IR pattern resembled that of black carbon (van der Marel and Beutelspacher, 1976; Durand, 1980). The relatively intense peaks at $1600 \mathrm{~cm}^{-1}$ and $1510 \mathrm{~cm}^{-1}$ and at $1450 \mathrm{~cm}^{-1}$ and $1365 \mathrm{~cm}^{-1}$, may correspond to aromatic and alkyl vibrations respectively (Wang and Griffiths, 1985), whereas new maxima at between $900-700 \mathrm{~cm}^{-1}$ may be due to substitutions in polycyclic structures characteristic of carbonized materials.

Similar evolution occurred in the unheated FA, where the intensity of the bands due to oxygen-containing functional groups $\left(1720 \mathrm{~cm}^{-1}, 1395 \mathrm{~cm}^{-1}, 1210 \mathrm{~cm}^{-1}\right.$ and $770 \mathrm{~cm}^{-1}$ ) decreased greatly. The major peaks corresponded to aromatic and alkyl 

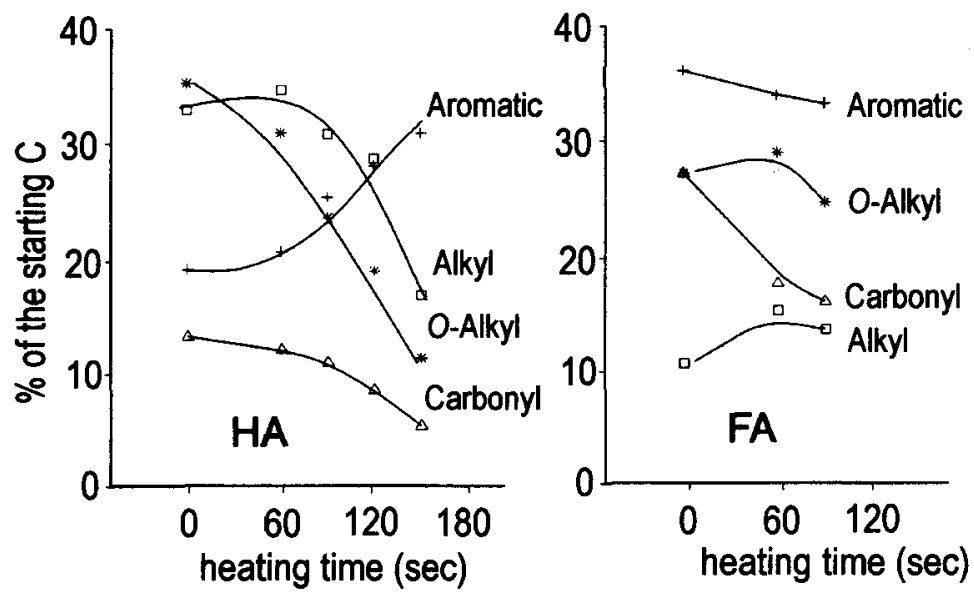

Figure 10. Depletion of the different C-types in the 13C-NMR spectra of HA and FA as a result of heating.

bending bands (at between 1550-1350 $\mathrm{cm}^{-1}$ ), but some alcoholic $\mathrm{OH}$ groups in carbohydrate-derived structures were suggested from the $1100-100 \mathrm{~cm}^{-1}$ region. As expected, the changes were not noticeable when comparing the HA or FA from the control soil sample with those from the heated one, the latter corresponding only to the humic portion that remains soluble into alkali, which will necessarily represent content or types of oxygen-containing functional groups similar to that of the unburnt humic substances.

The quantitative results from the integration of selected regions in the ${ }^{13} \mathrm{C}-\mathrm{NMR}$ spectra (not shown) of the progressively heated samples are shown in Figure 10 The percentages of the different $\mathrm{C}$ types are calculated in terms of the C-losses under laboratory conditions. In the case of the HA, the depletion of alkyl and $O$ alkyl materials was substantial; the amount of carboxyl $\mathrm{C}$ also decreased progressively, but that of aromatic $\mathrm{C}$ increased with the heating time. The latter fact is explained from the neoformation of unsaturated and/or aromatic material during the heating of $O$-alkyl constituents such are sugars, a phenomenon observed during carbohydrate dehydrations leading to the formation of melanoidins (Hodge, 1953; Hedges, 1978; Feather and Harris, 1973).

3.2.1.3. Assessment of alterations by chemical degradations. The alkaline permanganate oxidation of heated Has from the soil 1 (Table 1) is shown in Figure 11. Mainly $\alpha, \omega-$ alkanoic diacids, alkanoic monoacids, aromatic (benzenecarboxylic and phenolic) acids, and alkanes, were released. Although the most prominent chromatographic peaks were essentially the same in the different samples, differences were observed in the relative proportion of the compounds. The proportion of the lowestboiling-point alkanoic diacids tends to increase with heating, suggesting a thermal breakdown in aliphatic or alicyclic structures. The size of the peaks corresponding 

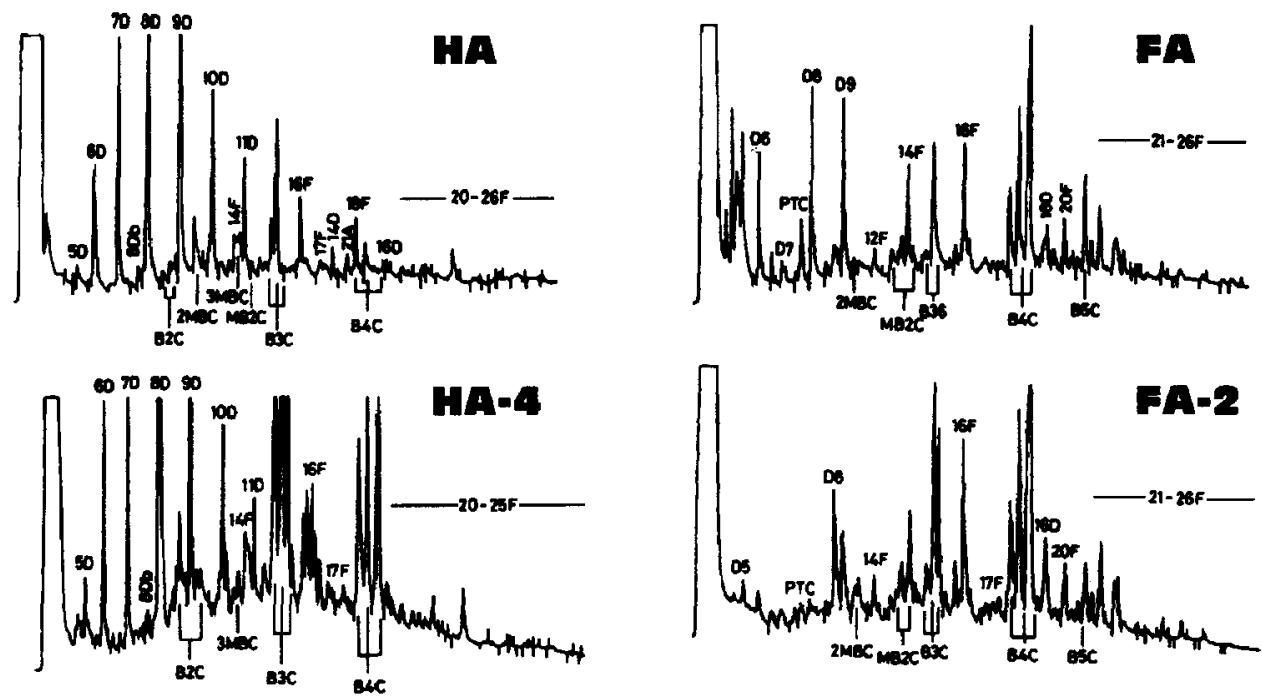

Figure 11. Changes on the relative abundance of the different alkaline permanganate oxidation products. The major products are labelled on the peaks. Letter $\mathrm{D}$ (followed by $\mathrm{C}$ range) refer to $\alpha, \omega$-alkanoic diacids. Letter F refer to fatty acids, B2C to B4C refer to benzenepolycarboxylic acids. Phenolic acids are marked with $\mathrm{M}$ and $\mathrm{B}$ (e.g. $3 \mathrm{MBC}=$ trimethoxybenzenecarboxylic acid). Labels refers to Figure 9.

to different benzenecarboxylic acids was comparatively higher, whereas the peaks of phenolic acids were more reduced in number and size. Such trends suggest also the expected selective thermal destruction of aliphatic and $\mathrm{OH}$-containing structures. Under laboratory conditions, the fatty acid patterns were found to be rather resistant to thermal effects, but a tendency to selective destruction of chains of a higher molecular weight $\left(>C_{16}\right.$ ) was observed. The $C_{14}$ and $C_{16}$ acids tended to be predominant under severe heating. Under natural conditions (Almendros et al., 1990), the pattern was different and a significant proportion of even-numbered, high-molecular-weight fatty acids in the Has were found. This circumstance could correspond to an incorporation of fatty acids derived from epicuticular waxes of the burned plant residues (Simoneit and Mazurek 1982), which may partially compensate for the thermal destruction of aliphatic structure in HAs (Almendros et al. 1988). The above phenomenon may be compared with that of thermal "fixation" of hydrophobic substances in the soil as described by Savage (1974). Similar trends were observed in the FAs: The peaks for $\alpha, \omega$-alkanoic diacids tend to be lower in number and in relative size, whereas the proportion of benzenecarboxylic acids was higher in the samples after burning.

In independent studies, the HAs extracted from whole soil samples after laboratory heating (soil 2) were degraded by successive treatments with sodium persulfate and potassium permanganate (Almendros et al., 1998). The results also showed that the relative yields of aromatic products were comparatively higher in the heated soil samples. The $\alpha, \omega$-alkanoic diacids were found to be the least resistant to heating, whereas greater amounts of alkanes in the less condensed macromolecular structures of the HAs were observed in the samples after burning. 
The persulphate treatment removed mainly the aliphatic molecules: fatty acids, alkanes and $\alpha, \omega$-alkanoic diacids. Some benzenecarboxylic and phenolic acids were also obtained: a dimethoxybenzenecarboxylic acid (comp. No. 20, Table 3) was the most abundant product released by persulphate oxidation in the control sample. Other important products were propanetricarboxylic acid (No. 7), p-methoxy cinnamic acid (No. 25), and phenyl propionate (No. 3), these compounds probably released during the lignin degradation processes. Pimaric acid was also detected in the persulphate digests, being probably entrapped in the humic structures, or perhaps linked by its carboxyl group (No. 63), but the quantities of this compound detected tended to be comparatively similar after heating. The distribution patterns of fatty acids associated with HA showed no important differences between the control sample and the heated samples.

The cumulative representation (Figure 12) showed that the total amount of alkanoic diacids decreased, whereas the fatty acid content was very constant even after the more severe thermal treatment. The proportion of $n$-alkanes, in forms released by persulfate, tends to be comparatively higher in the samples after heating. This fact partially offsets the relative decrease of the aliphatic character of the whole macromolecule due to heating, mainly by a selective destruction of the structures pro-

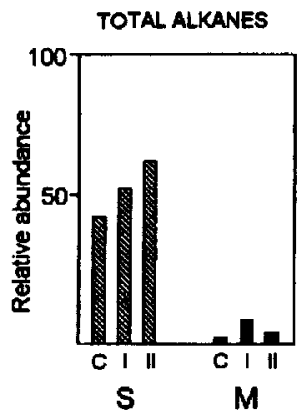

TOTAL FATTY ACIDS

BRANCHED FATTY ACIDS
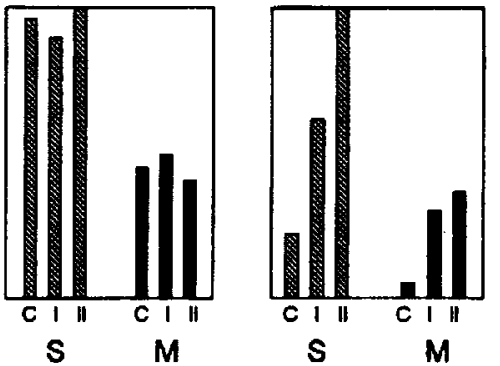

ALKANOKC DIACIDS

PHENOUIC

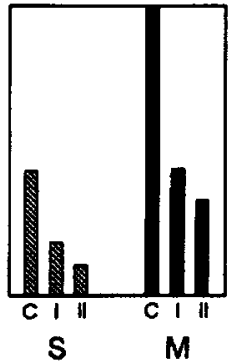

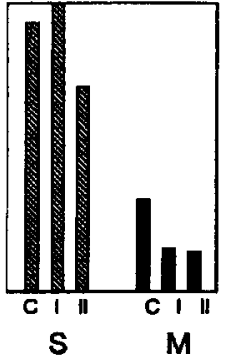

BENZENECARBOXYLK

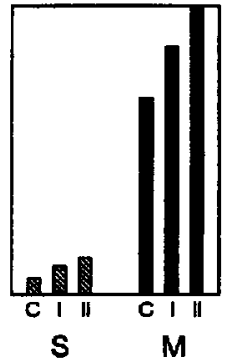

Figure 12. Proportional content of the major groups of organic compounds released by successive degradation with potassium persulfate $(\mathrm{S}$, dashed bars) and alkaline permanganate oxidation (M, solid bars) of HAs extracted from whole soils heated at $100{ }^{\circ} \mathrm{C}$. $\mathrm{C}=$ control samples, I, II, heated for 40 seconds (final average $\mathrm{T}=160^{\circ} \mathrm{C}$ ) or $80 \operatorname{secs}$ (final average $\mathrm{T}=210^{\circ} \mathrm{C}$ ). 
ducing alkanoic diacids. Branched or saturated fatty chains were more resistant in the conditions studied, and the benzenecarboxylic/phenolic ratio tended to be higher in the samples taken in a natural soils affected by wildfires and in the samples heated in the laboratory.

After permanganate degradation, the main peaks corresponded to different benzenepolycarboxylic acids, which represented more than half of the obtained products. In all the samples, the major compound was the 1,2,4-benzenetricarboxylic acid. Propanetricarboxylic acid was abundant in the control sample $(8 \%)$ but lower in the samples I and II. As in the case of the persulfate degradations, the series of fatty acids bonded to HA's presented a pattern relatively constant in the control and the heated samples (mainly the saturated and branched chains).

\subsubsection{Whole peat sample}

The effects of controlled heating on the quantitative distribution patterns of the different $\mathrm{C}$ and $\mathrm{N}$ forms in sapric peat have been assessed by the analysis of the elementary composition and the solid-state ${ }^{13} \mathrm{C}$ - and ${ }^{15} \mathrm{~N}-\mathrm{NMR}$ spectra of progressively heated peat samples. The alterations in peat elementary composition as consequence of progressive heating is shown in Table 7.

The data in Figure 13 clearly show that the loss of the major elements $(\mathrm{C}, \mathrm{H}, \mathrm{O}, \mathrm{N})$ followed non-linear trends. The losses of $\mathrm{O}$ and $\mathrm{H}$ were the most important, whereas the charred residue tends to be enriched in those elements $(C, N)$ presumably present in the most resistant-or newly formed-structures. These results coincided with the typical behaviour of soil HAs and FAs in the course of laboratory heatings (Almendros et al., 1990). In fact, when the changes are plotted in a van Krevelen (1950) diagram (not shown here), the progressive decrease of the atomic $\mathrm{H} / \mathrm{C}$ and $\mathrm{O} / \mathrm{C}$ ratios, corresponding to the expected dehydration reactions in the samples subjected to moderate heating (e.g. up to $90 \mathrm{~s}$ ) were evident, whereas decarboxylation and demethylation were the dominant reactions in the longer heated samples.

Concerning the changes in the $\mathrm{N}$ content, it is clear that such element is not preferentially depleted, showing a tendency to shift into structures fairly resistant to heating. The $\mathrm{C} / \mathrm{N}$ ratio remains relatively unchanged after moderate heating. However, its clear decrease in samples heated for more than 150 seconds seems to

Table 7. Elementary composition (ash free, $\mathrm{g} \mathrm{kg}^{-1}$ ) of peat samples subjected to progressive heating as a function of the oxidation time.

\begin{tabular}{cccccccc}
\hline $\begin{array}{l}\text { Oxidation time } \\
\text { at } 350^{\circ} \mathrm{C}(\mathrm{s})\end{array}$ & $\mathrm{C}$ & $\mathrm{H}$ & $\mathrm{N}$ & $\mathrm{O}^{*}$ & \multicolumn{2}{l}{ Atomic ratios } & \multirow{2}{*}{$\begin{array}{l}\mathrm{C} / \mathrm{N} \\
(\mathrm{w} / \mathrm{w})\end{array}$} \\
\hline 0 & & & & & $\mathrm{H} / \mathrm{C}$ & $\mathrm{O} / \mathrm{C}$ & \\
\hline 60 & 56.7 & 6.2 & 1.6 & 35.5 & 1.32 & 0.47 & 35.0 \\
90 & 57.6 & 6.0 & 1.6 & 34.8 & 1.25 & 0.45 & 34.3 \\
120 & 59.8 & 5.3 & 1.8 & 33.1 & 1.07 & 0.41 & 33.3 \\
150 & 65.0 & 4.6 & 1.9 & 28.5 & 0.87 & 0.33 & 33.6 \\
180 & 71.7 & 4.8 & 2.2 & 21.3 & 0.82 & 0.22 & 31.4 \\
\hline
\end{tabular}

*Calculated by difference. 


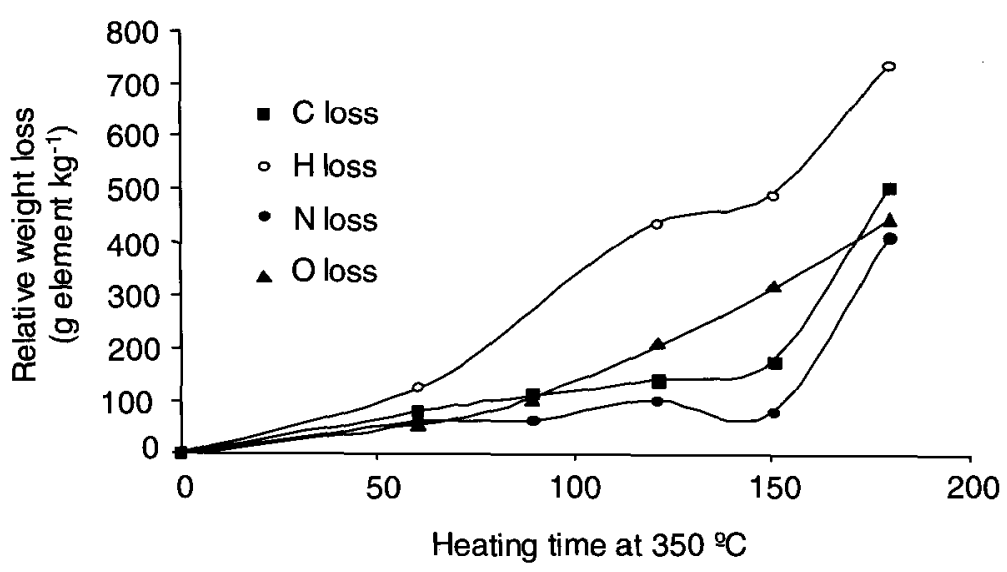

Figure 13. Loss of the major elements in peat samples subjected to laboratory heating.

indicate the accumulation of recalcitrant organic $\mathrm{N}$-forms in the black-carbon-like material. The same decrease in the $\mathrm{C} / \mathrm{N}$ ratio was observed in soils affected by wildfires (Almendros et al., 1984a).

The solid-state ${ }^{13} \mathrm{C}$ and ${ }^{15} \mathrm{~N}$ NMR spectra of the original peat and the samples obtained after progressive heating is shown in Figure 14. The relative intensity distribution of $\mathrm{C}$ and $\mathrm{N}$ forms is given in Table 8. Changes in the chemical composition of the heated samples are observed even after moderate heating (up to $90 \mathrm{~s}$ ). There was a weak enrichment of aromatic/olefinic $\mathrm{C}(160$ to $110 \mathrm{ppm})$ and a decreasing contribution of $O / N$-alkyl C (110 to $45 \mathrm{ppm}$ ), which changed from $31 \%$ of the $\mathrm{C}$ in the untreated peat to $22 \%$ in the sample heated for $90 \mathrm{~s}$. The relative intensities in the chemical shift of carbonyl C (220 to $160 \mathrm{ppm}$ ) and alkyl C (45 to $0 \mathrm{ppm}$ ) remained relatively constant.

It is clearly observed that progressive heating increased the aromaticity of the original peat to values typically found for charred material $(65 \%)$. This could in part be due to the relative enrichment of lignins, which is in agreement with the fact that in the spectrum of the sample heated for $120 \mathrm{~s}$ the signals of $O$-aryl C (160 to 140 $\mathrm{ppm}$ ) and methoxyl $\mathrm{C}$ ( 60 to $45 \mathrm{ppm}$ ) regions are still visible whereas that in the region for anomeric $\mathrm{C}$ (110 to $90 \mathrm{ppm}$ ) became indiscernible from the broad signal at $128 \mathrm{ppm}$. For this spectrum, the area between 90 to $60 \mathrm{ppm}$ decreased to $7 \%$.

With progressive heating time, the carbohydrate-related signals disappear whereas the alkyl $\mathrm{C}$ remain slightly affected up to $120 \mathrm{~s}$ when adecrease from $28 \%$ to $13 \%$ of the total ${ }^{13} \mathrm{C}$ intensity occurs. In particular, the intensity in the methoxyl $\mathrm{C}$ region decreases during heating suggesting that the lignin residues are selectively enriched in spite they have lost their methoxyl functionality. Nevertheless, in resistant plant macromolecules, apart from this selective enrichment it is also likely that a neosynthesis of unsaturated compounds must have occurred. According to the high loss of $\mathbf{H}$ (Figure 13), this may result from carbohydrate dehydration and transformations of alkyl concomitant with the formation of double bonds. 

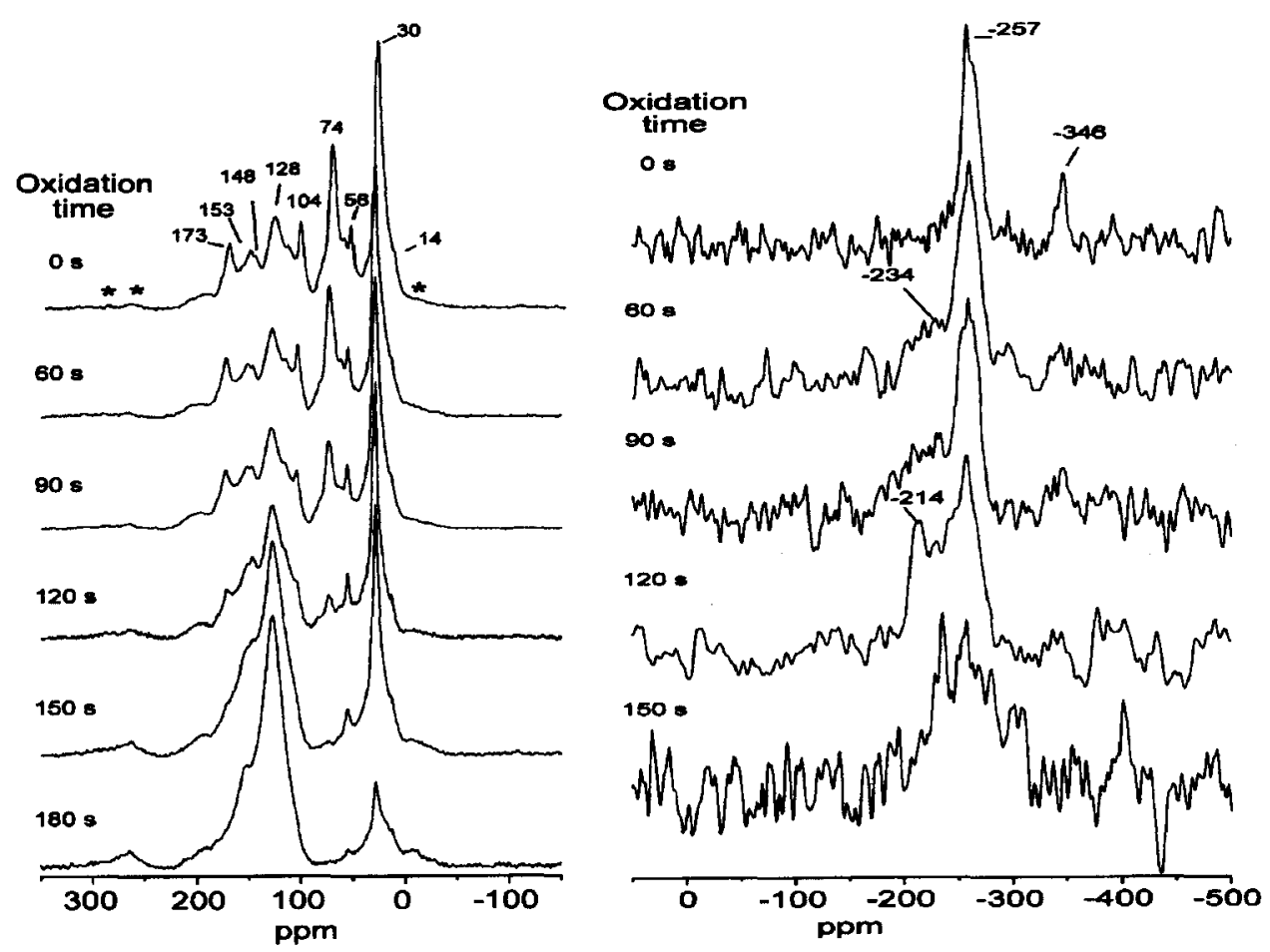

Figure 14. ${ }^{13} \mathrm{C}$ and ${ }^{15} \mathrm{~N}$ NMR spectra of peat samples subjected to laboratory heating at $350{ }^{\circ} \mathrm{C}$. Heating time in seconds is indicated with the spectra. *Spinning side bands.

The synthesis and probably cyclisation of unsaturated structures is affecting the chemical shift region between 140 and 110 ppm, but also that between 160 and 140 ppm. In fact, with progressive heating the ratio between their intensities does not change considerably (Table 8). This would either indicate the formation and accumulation of $O$-aryl or $C$-substituted unsaturated $\mathrm{C}$ structures.

In contrast to previous studies (Knicker et al., 1996) done on fresh grass material, the relative intensity in the carboxyl/carbonyl/amide region (220 to $160 \mathrm{ppm}$ ) does not show considerable changes during progressive heating. The calculated $\mathrm{C}$ losses in this region indicates that decarboxylation is not a major reaction that occurs during these early heating stages.

The black carbon-like residue (180 sec in Figure 14) practically consisted of aromatic and alkyl C-types. This ${ }^{13} \mathrm{C}$ NMR profile has often been compared to that of kerogens (Wilson, 1987). The fact that this final residue still contain more than $10 \%$ alkyl carbons suggest the possibility that not only aromatic structures are stabilised in the course of thermal treatment, but also some kind of aliphatic or alicyclic compounds. In fact, the ratio aromatic $\mathrm{C}$ to alkyl $\mathrm{C}$ calculated for the sample after 180 $\mathrm{sec}$ is around 5. This, in addition to the signal at $15 \mathrm{ppm}$ for terminal methyl groups, suggest that such alkyl carbons are not located to large extent in long-chain residual 
Table 8. Intensity distribution in the solid-state CPMAS ${ }^{13} \mathrm{C}$ and ${ }^{15} \mathrm{~N}$ NMR spectra of sapric peat and the corresponding residues obtained after progressive heating.

\begin{tabular}{|c|c|c|c|c|c|c|c|}
\hline \multicolumn{8}{|c|}{ CPMAS ${ }^{13} \mathrm{C}-\mathrm{NMR}$ spectra } \\
\hline \multirow{2}{*}{$\begin{array}{l}\text { Heating time } \\
\text { at } 350^{\circ} \mathrm{C} \\
\text { (sec) }\end{array}$} & \multicolumn{2}{|c|}{ Carbonyl C } & \multicolumn{2}{|c|}{ Aromatic C } & \multicolumn{2}{|c|}{$O / N$-Alkyl C } & \multirow{2}{*}{$\begin{array}{l}\text { Alkyl C } \\
45 / 0 \\
\text { ppm }\end{array}$} \\
\hline & $\begin{array}{l}220 / 160 \\
\text { ppm }\end{array}$ & $\begin{array}{l}160 / 140 \\
\text { ppm }\end{array}$ & $\begin{array}{l}140 / 110 \\
\text { ppm }\end{array}$ & $\begin{array}{l}110 / 90 \\
\text { ppm }\end{array}$ & $\begin{array}{l}90 / 60 \\
\text { ppm }\end{array}$ & $\begin{array}{l}60 / 45 \\
\text { ppm }\end{array}$ & \\
\hline 0 & 11.1 & 8.3 & 18.9 & 6.5 & 18.9 & 6.0 & 30.0 \\
\hline 60 & 11.8 & 9.0 & 20.5 & 5.7 & 16.3 & 5.5 & 31.3 \\
\hline 90 & 13.3 & 10.8 & 23.0 & 4.8 & 11.5 & 5.1 & 31.5 \\
\hline 120 & 11.4 & 13.5 & 29.4 & 5.5 & 7.0 & 5.4 & 28.0 \\
\hline 150 & 11.7 & 16.3 & 36.9 & 4.7 & 2.3 & 3.5 & 24.6 \\
\hline 180 & 11.7 & 18.7 & 48.7 & 4.8 & 1.1 & 1.6 & 13.3 \\
\hline
\end{tabular}

CPMAS ${ }^{15} \mathrm{~N}-\mathrm{NMR}$ spectra

\begin{tabular}{llllll}
\hline Heating time & Pyridine-type $\mathrm{N}$ & Pyrrole-type N & Amide N & \multicolumn{2}{l}{ Amino N } \\
\cline { 5 - 6 } $\begin{array}{l}\text { at } 350^{\circ} \mathrm{C} \\
(\mathrm{sec})\end{array}$ & $-25 / 145$ & $\begin{array}{l}-145 /-240 \\
\mathrm{ppm}\end{array}$ & $-240 /-285$ & $-285 /-300$ & $-330 /-350$ \\
\hline 0 & 1 & 8 & $\mathrm{ppm}$ & $\mathrm{ppm}$ & $\mathrm{ppm}$ \\
\hline 60 & 2 & 31 & 75 & 4 & 12 \\
90 & 1 & 41 & 58 & 4 & 5 \\
120 & 9 & 47 & 51 & 0 & 7 \\
150 & 7 & 43 & 39 & 1 & 3 \\
180 & n.d. & n.d. & 43 & 7 & 0 \\
\hline
\end{tabular}

paraffinic structures from e.g, plant waxes, but in some kind of methyl, methylene or hydroaromatic structures. These structures may be "fixed" as recalcitrant C forms in a predominantly aromatic matrices in which the residual aliphatic constituents are not readily susceptible for chemical or biological degradation (Tinoco et al., 2000). In particular, the presence of a substantial alkyl domain in pseudomelanoidins ( $\mathrm{N}$ lacking sugar-derived abiotic macromolecules) (Almendros et al., 1989) could be invoked to explain the heat-resistant aliphatic structures in said black carbon-like materials.

The figures in Table 9, where values greater than 100 indicated thermal neoformation reactions for the corresponding structures, are useful to differentiate selective depletion from the accumulation of newly-formed $\mathrm{C}$-forms. Thus, a neat increase of up to $60 \%$ was accounted for aromatic C. This increase was highest in the 160-110 $\mathrm{ppm}$ aromatic region, where up to $50 \%$ of these structures were formed as effects of heating. On the other hand, the negative balance for the aliphatic $\mathrm{C}$-forms was evident in the $O$-alkyl structures, where only $14 \%$ remain at the end of the experiment.

The above data suggest the occurrence of different stages during thermal alteration, similar to those indicated in previous studies using different materials (Almendros et al., 1984b, 1990; Tinoco et al., 2000). The early stages would correspond to 
Table 9. Recovered $\mathrm{C}$ of each $\mathrm{C}$ type during progressive heating calculated from the relative intensity distribution in Table 2 and the calculated total C-loss (Table 1).

\begin{tabular}{|c|c|c|c|c|c|c|c|c|c|}
\hline \multirow{2}{*}{$\begin{array}{l}\text { Heating time } \\
\text { at } 350^{\circ} \mathrm{C} \\
(\mathrm{sec})\end{array}$} & \multirow{2}{*}{$\begin{array}{l}\text { Carbonyl C } \\
220 / 160 \\
\text { ppm }\end{array}$} & \multicolumn{3}{|c|}{ Aromatic $\mathrm{C}$} & \multicolumn{4}{|c|}{ O/N-Alkyl C } & \multirow{2}{*}{$\begin{array}{l}\text { Alkyl C } \\
45 / 0 \\
\text { ppm }\end{array}$} \\
\hline & & $\begin{array}{l}160 / 140 \\
\text { ppm }\end{array}$ & $\begin{array}{l}140 / 110 \\
\mathrm{ppm}\end{array}$ & Total & $\begin{array}{l}110 / 90 \\
\text { ppm }\end{array}$ & $\begin{array}{l}90 / 60 \\
\mathrm{ppm}\end{array}$ & $\begin{array}{l}60 / 45 \\
\mathrm{ppm}\end{array}$ & Total & \\
\hline 0 & 100 & 100 & 100 & 100 & 100 & 100 & 100 & 100 & 100 \\
\hline 60 & 97 & 101 & 100 & 100 & 81 & 79 & 85 & 81 & 96 \\
\hline 90 & 107 & 116 & 108 & 111 & 66 & 54 & 76 & 61 & 94 \\
\hline 120 & 89 & 141 & 134 & 136 & 73 & 32 & 76 & 49 & 80 \\
\hline 150 & 87 & 163 & 162 & 162 & 59 & 10 & 47 & 28 & 68 \\
\hline 180 & 52 & 113 & 128 & 124 & 37 & 3 & 14 & 12 & 22 \\
\hline
\end{tabular}

diagenetic transformations affecting mainly oxygen-containing groups, where dehydration and decarboxylation would turn pyranoside structures into unsaturated rings. In these stages, presumably leading to shrinking and internal-cross-linking of originally flexible, "open" macromolecular three-dimensional structures, the molecular encapsulation of aliphatic molecules could be possible. In the advanced stages, the accumulation of polycyclic aromatic and the removal of the more stable alkyl ones accumulated in the rigid structures in the black carbon material could occur. The latter could be assimilated to a "thermal distillation" of hydrocarbons and other compounds of reduced reactivity not suitable to form covalent bonds through the endothermic reactions.

The CPMAS ${ }^{15} \mathrm{~N}-\mathrm{NMR}$ spectra of the peat samples, heated or not, are dominated by a major peak centered at between -220 to $-285 \mathrm{ppm}$ with maximum around $-259 \mathrm{ppm}$. In this region, resonances from amides, peptides, indoles, lactames and carbazoles are expected (Witanowsk et al., 1993). The respective signal of their free amino groups is observed at $-346 \mathrm{ppm}$. This pattern is similar to those found for compost from organic wastes (Almendros et al., 1991), natural soils and sediments (Knicker et al., 1993; Knicker and Hatcher, 1997) where it was generally interpreted as a dominance of amide $\mathrm{N}$ in peptides.

The ${ }^{15} \mathrm{~N}-\mathrm{NMR}$ spectra demonstrated that heating leads to continuous increase of the relative intensity in the chemical shift region (between -25 and $-240 \mathrm{ppm}$ ) of heterocyclic N. Even heating at $350^{\circ} \mathrm{C}$ only for 60 s induced changes in the chemical composition of the $\mathrm{N}$ structures, as revealed by the relative increase in the region of heterocyclic $\mathrm{N}$, mainly at expenses of that assigned to amide $\mathrm{N}$. This tendency continued up until a heating time of $120 \mathrm{~s}$. It is noted that, at this time around $36 \%$ of the total spectral intensity is still attributable to the amide $\mathrm{N}$ region, indicating a higher resistance of those structures towards thermal degradation than generally thought. In fact, the above persistence of amide structures may be explained by stabilizing cross-linking reactions in which peptides and/or amino acids are involved and that may have occurred during peat formation (Nguyen and Harvey, 1998). Another possibility would be a physical or steric protection, in the three-dimensional humic network during loss of $\mathrm{OH}$ groups and removal of entrapped volatile alkyl 
compounds. At first sight, the relative enrichment of heterocyclic aromatic $\mathrm{N}$ during thermal treatment occurring concomitantly with the decrease of amide $\mathrm{N}$, this hs been also reported from pyrolysis studies of algaenan and of grass material (Derenne et al., 1993; González-Vila et al., 2001b). This observation may be interpreted as a selective preservation and accumulation of heteroaromatic structures that were already present in low amounts in the untreated peat, while the more labile peptide structures are preferentially degraded. Nevertheless, the relative intensity distribution of the solid state ${ }^{15} \mathrm{~N}$ spectra calculated in terms of the measured $\mathrm{N}$ loss, clearly show newly-formed heterocyclic material: After $60 \mathrm{~s}$ of heat treatment, the amount of $\mathrm{N}$ bound in pyrroles or indoles increased from $8 \%$ in the untreated sample to $27 \%$. This quantitative balance demonstrates that heterocyclic N-compounds, were newly formed, possibly by auto-condensation reactions from $\mathrm{NH}_{3}$ released and aromatic compounds, or through Maillard-type reactions. The latter is known to produce amide bonds, which may support the explanation for the accumulation of resistant amide functional groups after severe heating. Further reactions that may contribute to the formation of heterocyclic $\mathrm{N}$ structures could be cyclisation of aliphatic chains in the presence of amino groups or $\mathrm{NH}_{3}$, or the cyclisation of peptide chains. All these compounds contribute to the formation of such heterocyclic structures would also add to the increase of relative intensity in the region between 140 and $110 \mathrm{ppm}$.

\subsubsection{Lignocellulosic biomass}

The balance between the different $\mathrm{C}$ and $\mathrm{N}$ forms in plant biomass during progressive heating has been studied by analytical pyrolysis and NMR spectroscopy. This approach would provide information on the signature of molecular assemblages useful to assess the effect of heating on lignocellulosic substrates. The elemental composition, and $\mathrm{C}$ and $\mathrm{N}$ losses of the heated plant material are shown in Table 10.

The values suggest that large structural transformation after a heating time over $45 \mathrm{~s}$ took place. When subjected to mild heating (up to approximately $20 \%$ weight is lost at $350{ }^{\circ} \mathrm{C}$ ) the major changes were the removal of the constitutional water and some oxygen-containing groups. The classical observation that the aliphatic

Table 10. Elementary composition $\left(\mathrm{g} \mathrm{kg}^{-1}\right)$ and calculated $\mathrm{C}$ and $\mathrm{N}$ losses $\left(\mathrm{g} \mathrm{kg}^{-1}\right)$ of Lolium rigidum subjected to progressive heating at $350^{\circ} \mathrm{C}$ as a function of oxidation time.

\begin{tabular}{|c|c|c|c|c|c|c|c|c|}
\hline \multirow{2}{*}{$\begin{array}{l}\text { Oxidation } \\
\text { time (s) }\end{array}$} & \multirow[t]{2}{*}{$\mathrm{C}$} & \multirow[t]{2}{*}{$\mathbf{H}$} & \multirow[t]{2}{*}{$\mathbf{N}$} & \multicolumn{2}{|c|}{ Atomic ratios } & \multirow[t]{2}{*}{ C-loss* } & \multirow[t]{2}{*}{$\mathrm{N}-$ loss* } & \multirow[t]{2}{*}{$\mathrm{C} / \mathrm{N}(\mathrm{w} / \mathrm{w})$} \\
\hline & & & & $\mathrm{H} / \mathrm{C}$ & $\mathrm{O} / \mathrm{C}$ & & & \\
\hline 0 & 341 & 49 & 55 & 1.72 & 1.21 & 0 & 0 & 6.2 \\
\hline 30 & 348 & 48 & 56 & 1.65 & 1.17 & 76 & 76 & 6.2 \\
\hline 45 & 352 & 48 & 59 & 1.63 & 1.15 & 116 & 120 & 6.0 \\
\hline 60 & 310 & 39 & 53 & 1.51 & 1.44 & 340 & 304 & 5.8 \\
\hline 75 & 277 & 21 & 40 & 0.91 & 1.78 & 469 & 655 & 6.9 \\
\hline 90 & 228 & 18 & 33 & 0.94 & 2.36 & 722 & 761 & 6.9 \\
\hline
\end{tabular}

$* \mathrm{~N}$-loss (as g kg-1 initial N) was calculated as $=1000(1000(\mathrm{~N}(1000$-weight loss $) / 1000) /$ initial N. Similar calculation was performed in the case of the C-loss. 

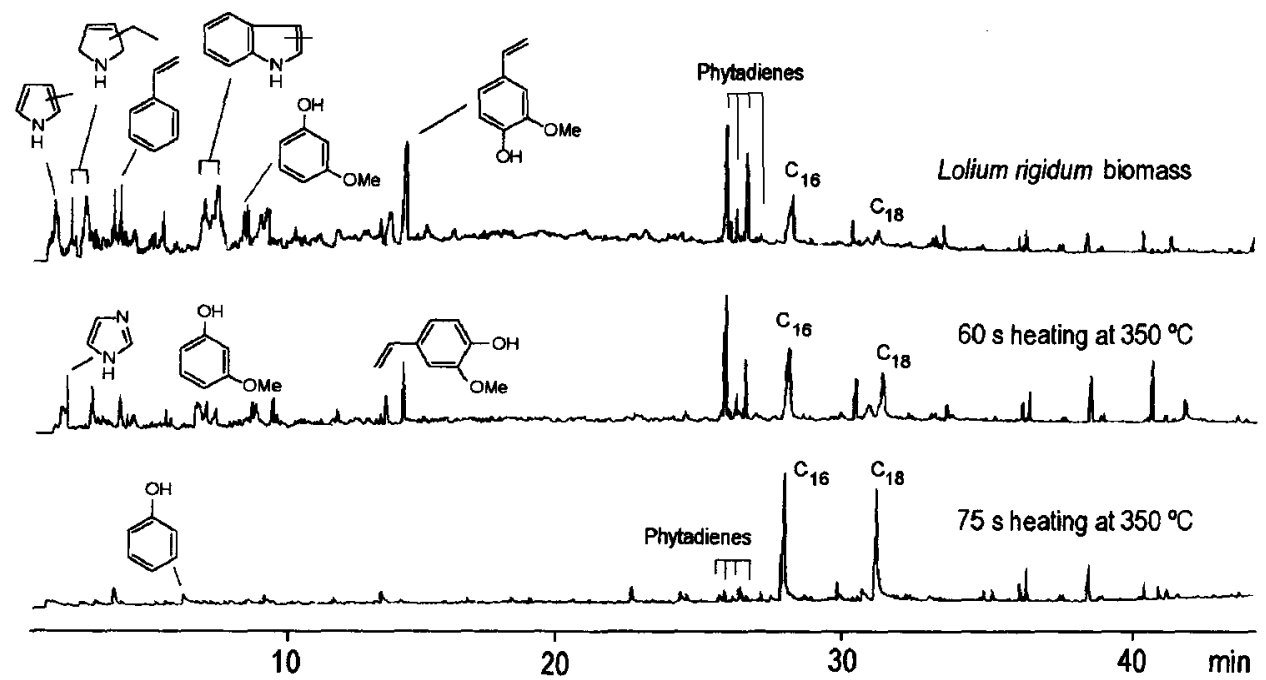

Figure 15. Pyrograms of Lolium rigidum biomass subjected to progressive isothermal heating.

material is comparatively less resistant than the aromatic (van Krevelen, 1950) is supported by the changes observed in the $\mathrm{H} / \mathrm{C}$ atomic ratios. The values for the biomass heated above $75 \mathrm{~s}$ are similar to those for humic substances, but the latter incorporates much more oxygen-containing products.

The pyrograms (Figure 15) produced by the samples that were heated up to $60 \mathrm{~s}$ resembled those from the original biomass, with the peaks arising from carbohydrates and proteins progressively decreasing with heating time. This is an indication that the C-backbone of the main plant biomacromolecules remains relatively stable in the torrefied biomass. The pattern dramatically changes after heating for $75 \mathrm{~s}$ with the pyrograms dominated by aromatic molecules, free fatty acids, and some esters and sterols. This is because plant macromolecules have undergone progressive rearrangements leading to a relative concentration of aromatic products with a decrease in the methoxyphenol/phenol ratio.

Figure 16 shows the relative yields of different groups of individual pyrolysis compounds calculated as percentages of the total volatile products. The phytadiene isomers are intermediate products in the degradation of chlorophylls (Grossi et al., 1996), leading to phytenes and pristenes, which are typical pyrolysis products of kerogen (Shyoya and Ishiwatari, 1983; Ishiwatari et al., 1990). The alkyl products show diagnostic yields in terms of heating time, the major changes being observed in the phytadienes and fatty acids, whereas the yields of paraffinic structures, waxes and sterols were comparatively more stable in terms of the heating intensity. In particular the pyrolytic data illustrate that progressive heating cannot be monitored through the presence of newly-formed aromatic structures in the volatile phase. In fact, this is confirmed by the poor yields of pyrolysis products obtained from activated charcoal under the same conditions. 


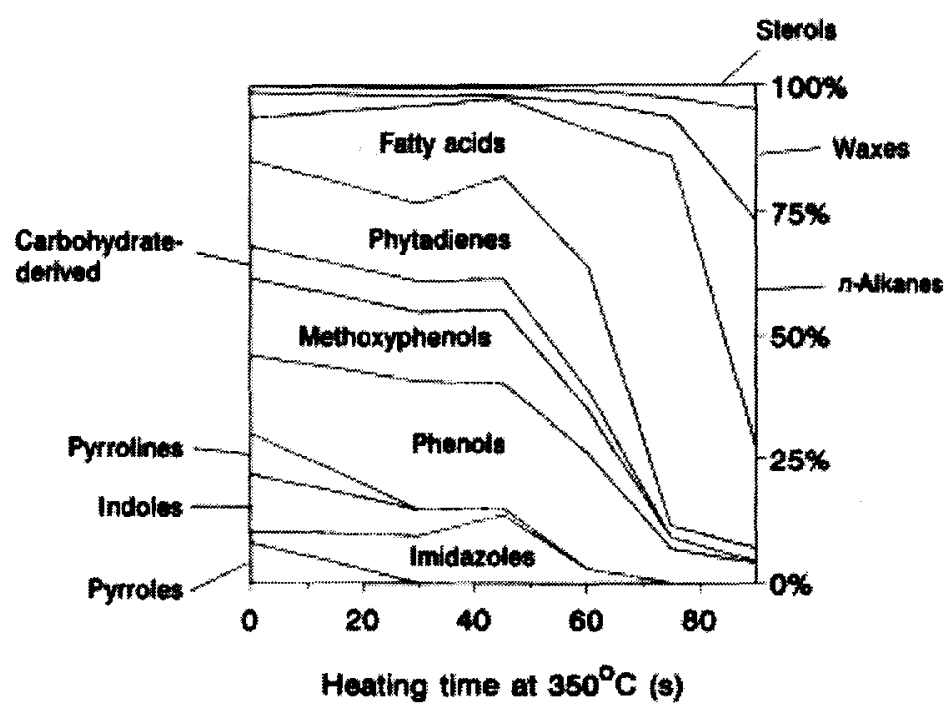

Figure 16. Changes in the relative yields of the major groups of pyrolysis products from Lolium rigidum biomass subjected to progressive isothermal heating.

Concerning the evolution of the different families of $\mathrm{N}$-containing pyrolysis compounds, our results are compatible with the fact that, in the final stages, the amide nitrogen is incorporated into heterocyclic structures i.e. pyrrols, imidazoles and indoles. Some evidence for pyridines and phenazines was also found. This is in agreement with the previous observation (Knicker et al., 1996) that the ${ }^{15} \mathrm{~N}-\mathrm{NMR}$ spectra of heated lignocellulosics contains large concentrations of heterocyclic $\mathrm{N}$ compounds although, in the biogenic organic matter, amide $\mathrm{N}$-forms dominate both in hydrolyzable as well as the recalcitrant fractions (Almendros et al., 1991; Knicker et al., 1993; Knicker and Lüdemann, 1995).

Figure 17 shows the solid-state ${ }^{13} \mathrm{C}$ - and ${ }^{15} \mathrm{~N}-\mathrm{NMR}$ spectra of the heat-treated grass as a function of heating time. The line broadening may suggest the progressive transformation of the original biopolymers into condensed macromolecular substances of chaotic structure.

Apart from carboxyl groups, other functional groups which may contribute to the region, between 220 and $160 \mathrm{ppm}$, are acetyl-groups in hemicelluloses or wax esters or cutans. However, the high total $\mathrm{N}$ content of approximately $5 \%$ and the low $\mathrm{C} / \mathrm{N}$ ratio of about 7 suggests that approximately $10 \%$ of the total $\mathrm{C}$-content is in the form of $\mathrm{C}=\mathrm{O}$ in such peptide structures. This could be due to the fact that most of the relative intensity of the aliphatic chemical shift region in the untreated grass solid-state ${ }^{13} \mathrm{C}$-NMR spectrum results from peptides and peptide-like structures rather than from paraffinic structures of plant waxes.

The semiquantitative characterisation of the transformations occurring during thermal treatment was carried out by considering the relative distribution intensities of the $\mathrm{C}$ signals in function of the calculated total C-loss of the samples. The data (not shown here) confirmed the following alterations: 

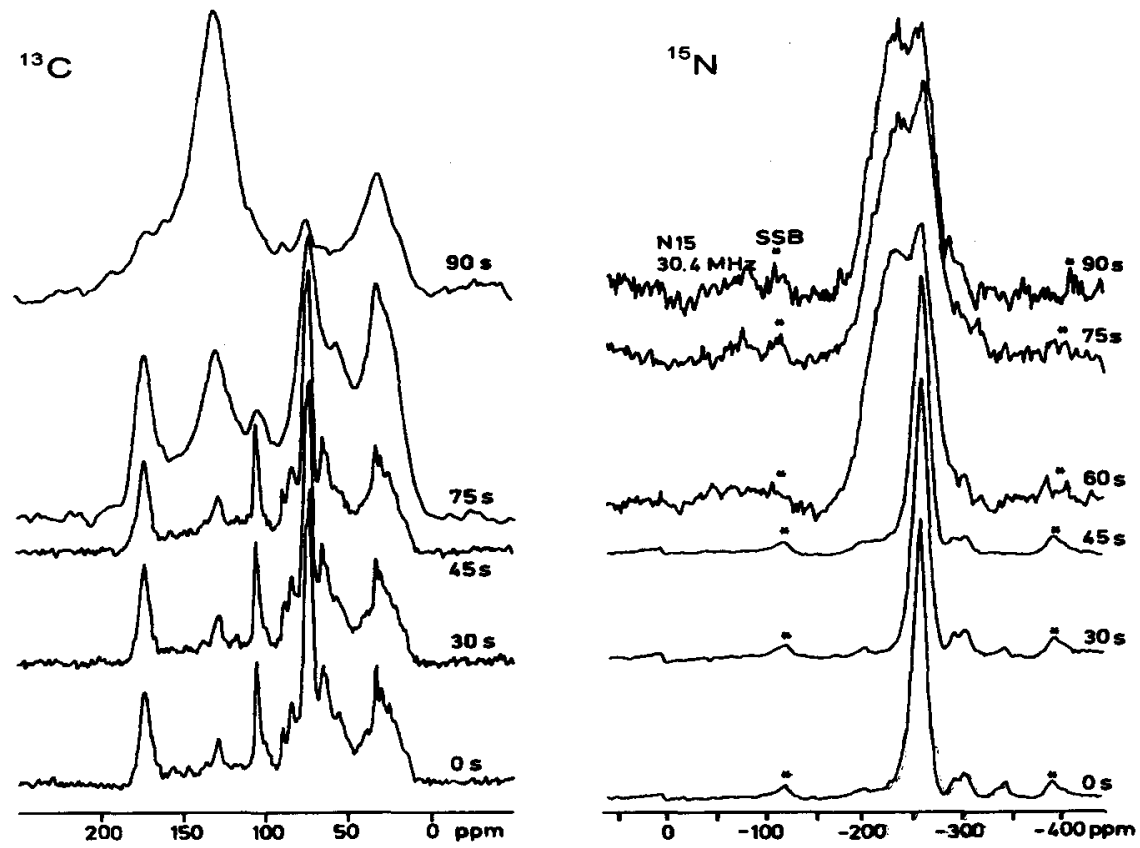

Figure 17. Changes in the CPMAS ${ }^{13} \mathrm{C}$ - and ${ }^{15} \mathrm{~N}-\mathrm{NMR}$ spectra of Lolium rigidum biomass subjected to progressive isothermal heating.

1. The carbohydrate signals in the 110 to $60 \mathrm{ppm}$ range, decreases in intensity, while the aromatic region from 160 to $110 \mathrm{ppm}$, showed a concomitant increase.

2. There is no $\mathrm{C}$ loss in the aromatic domains. A possible explanation may be the thermal conversion of carbohydrates into cyclic compounds such as anhydrosugars, cyclic ketones and furfurals. After $90 \mathrm{~s}$ of thermal treatment, the formation of polycyclic structures may also contribute to the large peak observed in the region $160-110 \mathrm{ppm}$.

3 . The decrease in signal intensity between $80-60 \mathrm{ppm}$ is consistent with the carbohydrate dehydration and the formation of double bonds, as reflected by the increased signal intensity in the $140-120$ ppm range.

4. The considerable decrease in the $220-160$ ppm region -assigned to carbonylscan be interpreted as the degradation of $\mathrm{C}-\mathrm{N}=$ bonds due to the decomposition of amino and amide groups in peptides and/or the decarboxylation of aliphatic carboxylic acids. However, a large intensity of the $175 \mathrm{ppm}$ signal is noted even after a weight loss of $c a$. $50 \%$, suggesting that heat-resistant polyester structures and melanoidin material are preserved in the blackcarbon-like grass residue.

5. The decrease of signal intensity and the observed $C$ loss in the alkyl region ( 45 to $0 \mathrm{ppm}$ ) as a result of thermal treatment, can be explained by the demethylation of aliphatic chains from lipids and amino acids, but also, to a simultaneous formation of olefins. 
The solid-state ${ }^{15} \mathrm{~N}-\mathrm{NMR}$ spectrum of the unburned sample (Figure 17) is dominated by the signal at $-257 \mathrm{ppm}$, assigned to amides and that at $-345 \mathrm{ppm}$ in the chemical shift range of free aliphatic amino groups. With increasing burning time the intensities of both signals decreased in percentage area. The latter completely disappearing after $45 \mathrm{~s}$ of burning, indicating a degradation of proteins and free amino acids, which is compatible with their conversion into heterocyclic compounds.

The most striking fact in these spectra is the increase in the relative signal intensity in the region at between -145 to $-240 \mathrm{ppm}$ assigned to indoles, imidazoles and pyrroles. This points to the preservation of such compounds due to their resistance to thermal degradation or, as discussed above, due to the accumulaton of newlyformed heterocyclc $\mathrm{N}$-compounds with a rearrangement and the formation of melanoidins or peptides cyclisation. Evidence for the latter was suggested by Boon and de Leeuw (1987).

All spectra, even after $90 \mathrm{~s}$ of thermal treatment, show signal intensity at -257 ppm pointing to the presence of recalcitrant amides that are not affected by heat. Such amide structures may contribute substantially to the insoluble fraction (humin, black carbon, kerogen) of soil and sedimentary organic matter and which, in general, is refractory to standard wet chemical procedures.

The results suggest that, in agreement with Wang and Low (1990), two stages could be distinguised:

1. In the early heating stages, with $\mathrm{C}$ loss of up to $12 \%$, chars are formed and aromaticity increase with heating (Solum et al., 1989). Solid-state ${ }^{13} \mathrm{C}$ and ${ }^{15} \mathrm{~N}$ NMR spectra demonstrates that in this stage the carbonaceous backbone of the main plant structural biomacromolecules remains relatively stable and that mainly free amino acids are removed.

2. A decrease of the yields of aromatic pyrolysis products, defined the second transformation stage. The simultaneous increase in the yields of paraffinic compounds can be explained considering that a typical feature of the charred materials is the thermal conversion of alkanes into non-volatile products (Remmler and Kopinke, 1995). According to the NMR data the different polymeric moieties are subjected to structural rearrangement. In fact, the results indicate that newly-formed aromatic structures make a substantial contribution to this effect. However, the aliphatic constituents show significant differences in thermostability, the most labile fraction being the $O$-alkyl carbons, whereas paraffinic structures are comparatively recalcitrant.

\subsubsection{Analytical characterization of heated cellulose preparations}

Thermal alteration of pure cellulose is used as a model for studying non-biological transformation processes of carbohydrates that lead to resistant macromolecular browning products. This approach is of interest to understand thermally-altered molecular structures of fossil organic sediments or SOM affected by fire (Dennis et al., 1982; Almendros et al., 1990).

The elementary composition of heated cellulose-derived substances involve large structural changes of the original material. The atomic ratios for the heated celluloses may indicate the accumulation of non-carbohydrate, unsaturated skeletal structures. 
Table 11. Elementary composition of heated cellulose-derived browning products.

\begin{tabular}{llllll}
\hline Heating time at $350^{\circ} \mathrm{C}(\mathrm{s})$ & $\mathrm{C}$ & $\mathrm{H}$ & $\mathrm{O}$ & \multicolumn{2}{l}{ Atomic ratios } \\
\cline { 4 - 6 } & & & & $\mathrm{H} / \mathrm{C}$ & $\mathrm{O} / \mathrm{C}$ \\
\hline 120 & 43.4 & 6.4 & 6.4 & 1.77 & 0.87 \\
150 & 44.0 & 6.3 & 6.3 & 1.72 & 0.85 \\
180 & 47.9 & 5.8 & 5.8 & 1.45 & 0.73 \\
\hline
\end{tabular}

In the IR spectra (Figure 18) of the heated celluloses, it can be seen how the original carbohydrate profile is progressively shifting as influenced by heat. In the heated samples, the intense $1620 \mathrm{~cm}^{-1}$ band observed is probably due to the presence of newly-formed aromatic rings. However, the intensity of this unspecific band is influenced by different groups in which double-bonding is involved. Structures with a potential high degree of resonance, such are quinone/semiquinone may contribute in this IR region (Mathur, 1972). That kind of structures may contribute to the intense black color in the humic substances. On the other hand, Pastorova et al. (1994) suggested that these are also responsible for stable free-radical based structures in charred celluloses. These samples showed an additional $1720 \mathrm{~cm}^{-1} \mathrm{C}=\mathrm{O}$ band but the intensity of the major carbohydrate band with a maximum at ca. 1040 $\mathrm{cm}^{-1}$ remains high. The heating also caused the progressive disappearance of the $1460 \mathrm{~cm}^{-1}$ alkyl bending band, and the 1160 and $1080 \mathrm{~cm}-1$ peaks ( $v-C O C$ and $v_{\text {as }}$ ring, respectively) which indicates a breakdown of the original pyranose rings.

The formation of aromatic units from the original carbohydrate is also indicated in the ${ }^{13} \mathrm{C}$-NMR spectra of the charred celluloses (Figure 18), this suggests a depletion of the oxygen-containing groups in most of the ring carbons, as expected to occurs during heating in a dry state. Nevertheless, the ${ }^{13} \mathrm{C}-\mathrm{NMR}$ spectra still suggest the presence of resistant carbohydrate structures in the samples heated for longer time. At least in their skeletal patterns, and shows a low signal intensity in the range that corresponds to aromatic and alkyl carbons.

A representative pyrogram of a heated cellulose preparation (180 s) is shown in Figure 19, the chemical structure of the major products are indicated on the peaks. The most abundant pyrolysis product was identified as levoglucosan, but other characteristic carbohydrate pyrolysis products (i.e. furanes and benzofuranes) and typical rearranged molecules (benzene, phenol, etc), were also found. The latter also included aromatic, heteroaromatic and hydroaromatic products, mainly saturated and unsaturated alkylbenzenes, indenes and naphthalenes.

The heated cellulose preparation pyrogram, show increased yields of aromatic molecules, including most furanes, whereas the yield of alkyl molecules (mainly shortchain ketones and unsaturated structures) was higher in the samples heated for a shorter time. This reflects the expected reactions of $\mathrm{OH}$ removal from the pyranosic units, with the concomitant unsaturation and ring opening (Hodge, 1953; Feather and Harris, 1973). The pyrolytic compound assemblages showed a large diversity of aromatic and unsaturated structures not existing in the original sample, that in the 

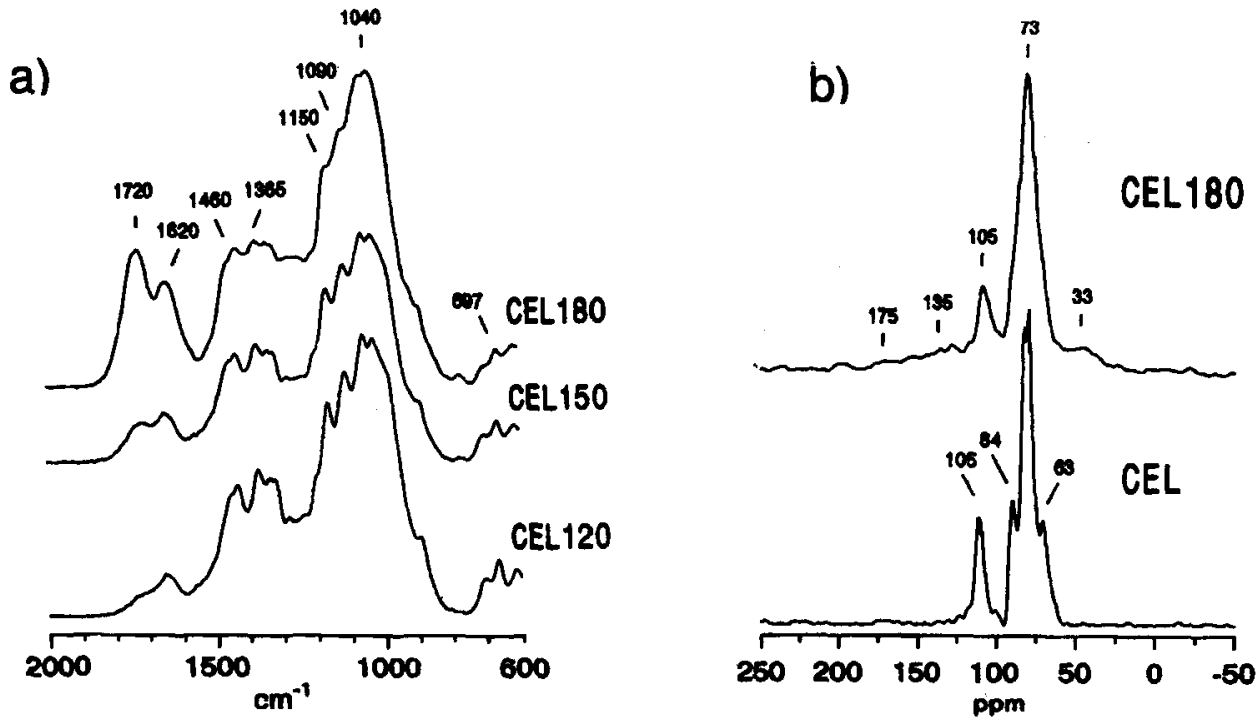

Figure 18. Fourier-transformed infrared (a) and ${ }^{13} \mathrm{C}-\mathrm{NMR}$ (b) spectra of heated cellulose preparations. Numbers after the labels refers to the heating time at $350{ }^{\circ} \mathrm{C}$ in seconds.

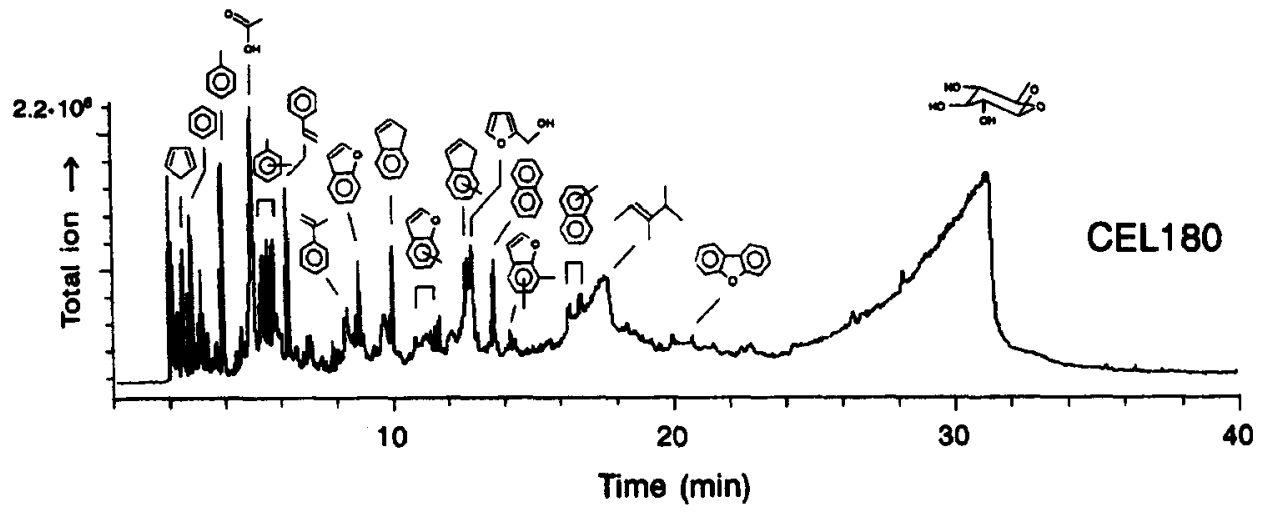

Figure 19. Pyrolytic pattern of a heated cellulose preparation.

samples heated for a longer time, increased when compared with the typical anhydrosugar products.

For the heated cellulose and under our experimental conditions, the yields for aromatic compounds were low, as suggested by the IR and ${ }^{13} \mathrm{C}$ NMR spectra. In these preparations the analytical pyrolysis shows the dominance of diagnostic molecules for carbohydrate, even after $50 \%$ wt loss. In fact, it is considered that the original $\beta-(1 \rightarrow 4)$ glycosidic linkage remain in cellulose chars up to the relatively high temperature of $270^{\circ} \mathrm{C}$ (Pastorova et al., 1994). 


\section{Conclusions}

The different approaches used here to study the effects of fire on SOM and related materials allowed the detection of a set of structural changes, which can be summarized as follows:

\subsection{Organic matter thermal perturbations in burned soils under natural and laboratory controlled conditions}

In the soils affected by forest fires under natural conditions, a decrease in both FA and free organic matter and an increase in HA and humin, is observed. The distribution patterns of soil lipids also undergoes substantial changes: i.e. the accumulation of the homologues (alkanes, fatty acids) of low molecular weight $\left(<\mathrm{C}_{24}\right)$; For diterpene compounds an increase in dehydroabietic and secodehydroabietic acids and decrease in pimaric acid is observed.

Laboratory-controlled heating experiments of whole soils confirm most of the processes previously observed in the fire-disturbed natural soils, providing also a valuable additional information to elucidate the different stages of a thermal decomposition. Depending on the heat intensity, the SOM undergoes quantitative and qualitative modifications that, in turn, may influence different relevant ecological processes. In experimental conditions miming those of a low-intensity fire, a decrease of the organic fractions with lower humification degree and an increase in aromaticity, is readily seen. The concentration of HA increase, showing a high proportion of nonhydrolysable constituents and high condensation degree. When modeling a forest fire under more drastic conditions, the soil organic fractions start to shift into refractory, black carbon-like substances, then, both peripheral constituents of the HA molecules and clay-humus complexes are destroyed and the $\mathrm{N}$ content and cation exchange capacity of the humic fractions sharply decreases.

\subsection{Effects of heating on isolated humic fractions}

The most generic effect exerted by fire is a change in the solubility properties of the soil humic fractions that is in relation with changes in the humus chemical composition.

In medium-intensity fires, the HA and FA undergoes important changes in their colloidal properties. In an early heating stage, the HA is transformed into an alkali-insoluble macromolecular material, and the insolubility drastically increased in subsequent phases. This transformation is more apparent in the FA, this is first transformed into an acid-insoluble macromolecule (HA-like) and then into an alkali-insoluble substance (humin or black carbon-like residue). Through wet chemical degradation and solid-state ${ }^{13} \mathrm{C}$-NMR studies, an increase in aromaticity and condensation degree and in the non-hydrolysable $\mathrm{N}$ content is observed, whereas the proportion of carbohydrate-like structures and O-containing functional groups 


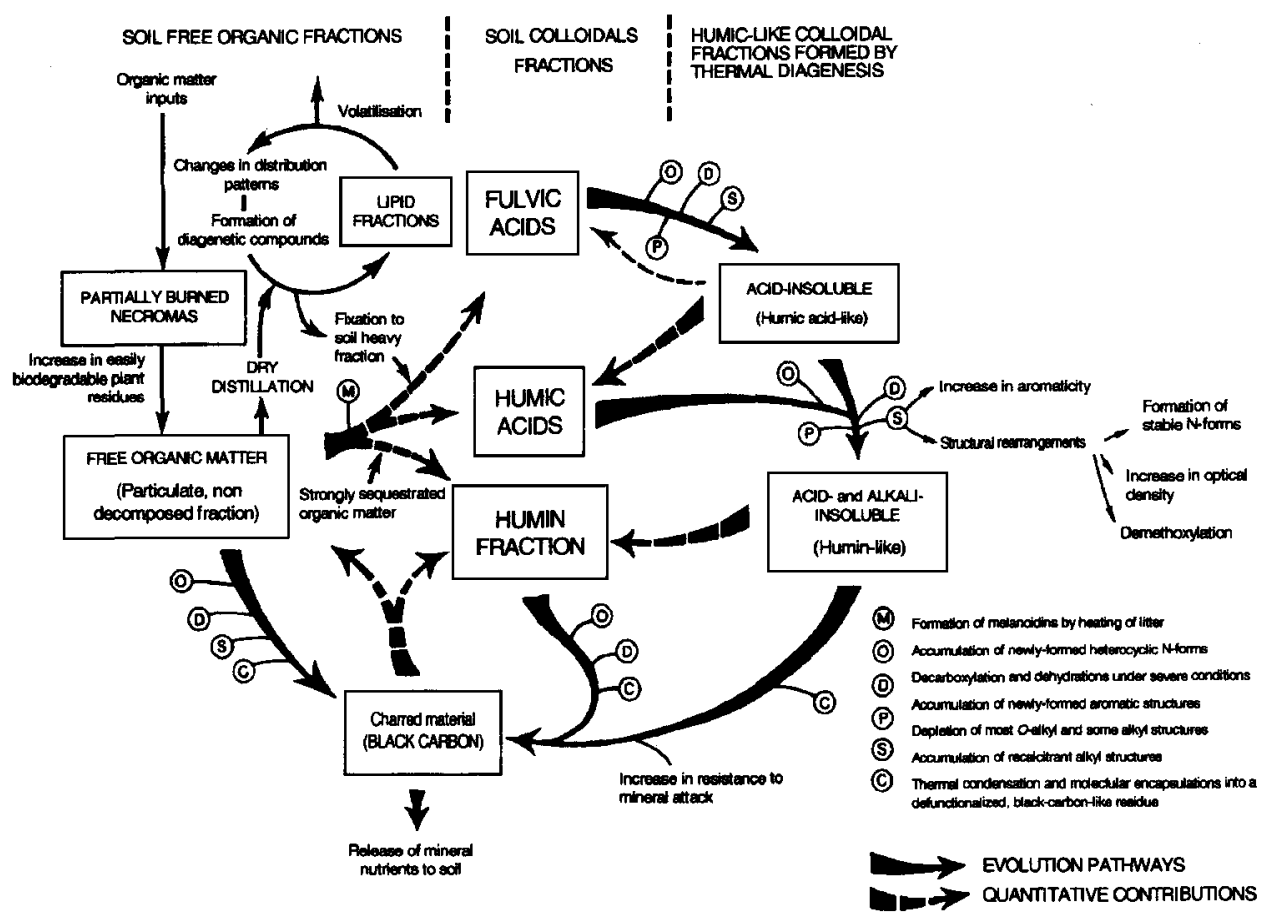

Figure 20. Hypothetical processes occurring in the organic matter of soils affected by fire.

decreases. The resolution enhanced FT-IR spectroscopy studies revealed that the well-defined lignin pattern in the original HAs tend to disappear with heating.

Said structural changes in the humic substances are postulated to have a direct effect on an increased resistance of the burned humus to biological transformations. In addition, the major effect of heat exerted changes is the destruction of the soil colloidal properties, with a probable role in increasing soil hydrophobicity.

A generic model on the fire-induced changes on the SOM, inferred from the above results is depicted in the Figure 20.

\subsection{Effects of controlled heating on organic materials related to soil or- ganic matter}

Heating increases the aromaticity of peat to values typical for black carbon material, but these charred residues (at least after weight losses of ca. $25 \%$ ) still contain heat-resistant alkyl carbon. Theere is a progressive formation of pyrrole- and indole-type compounds. Increasing concentrations of aromatic C-types and heterocyclic $\mathrm{N}$-forms with progressing heating are not relative effects of the selective thermal degradation of labile structures (mainly $O$-alkyl and amides) but corresponds to newly-synthesised molecules formed from aliphatic materials. Similar trends are observed in heated lignocellulosic biomass. By progressive heating the 
amide- $\mathrm{N}$ turns into heterocyclic structures such as pyrroles, imidazoles and indoles. However, most of the amide $\mathrm{N}$-forms are resistant to the thermal treatment. These findings suggest that a major portion of the $\mathrm{N}$ occurs in forms that may survive most natural fires and that heating increases their stability towards further microbial degradation.

Curie-point pyrolysis-GC/MS of progressively heated peat and biomass materials supports the previous findings that, even charred residues after severe heating (C loss $\mathrm{ca} .50 \%$ ) still contain substantial amounts of some resistant plant structural components, and, the accumulation of newly formed N-containing compounds and the existence of a heat-resistant alkyl domain that may survive natural fires. NMR and pyrolysys studies on charred celluloses ilustrated the occurrence of resistant carbohydrate structures (even after $48 \%$ wt loss), at least in their skeletal patterns. These results suggest the possibility that natural materials referred to as "carbohydrate-free macromolecules" can in fact consist of rearranged skeletal structures inherited from thermally or diagenetically altereded sugar precursors.

\subsection{Concerning the structure of black carbon}

The black carbon-like substances characterised in the present studies may consist of a highly unsaturated, three-dimensional network that include discrete domains of diagenetically altered plant structural biomacromolecules i.e. carbohydrate dehydration products together with condensed regions with polycyclic aromatic and heterocyclic newly-formed structures. This material contains high amount of non-hydroxyl, endo- and exocyclic oxygen and some nonhydrolysable ester groups. It is also probable that some of the products identified could be entrapped molecules in peripheral association through $\mathrm{H}$-bonding and charge-transfer interactions.

The black coal formation mechanisms suggest that at least two formation stages can be distinguish with a different implication on the accumulation of stable $\mathrm{C}$ and $\mathrm{N}$ forms in soils. The early stage is characterised by rapid loss in weight, mainly of hydrophilic groups, leading to the concentration of aromatic structures and of recalcitrant, newly-formed $\mathrm{N}$ compounds. An advanced stage probably involves freeradical condensation reactions of heat resistant materials with paraffinic structures tightly bound to a recalcitrant, structurally condensed charred residue.

\section{Acknowledgements}

The authors wish to thank the Spanish CICyT for grants AMB1999-0907 and AMB 1999-0226, as well as to the Spanish-German action HA 2000-0059 from the Spanish MCyT for allowing meetings and the mobility of the scientists involved in this research. 


\section{References}

Almendros, G, Polo, A., Ibáñez, J. and Lobo, M. C. (1984a) Contribución al estudio de la influencia de los incendios forestales en las características de la materia orgánica del suelo. I: Transformaciones del humus en un bosque de Pinus pinea del Centro de España. Rev. d'Ecol. Biol. Sol. 21, 7-20.

Almendros, G., Polo, A., Lobo, M. C. and Ibáñez, J. (1984b) Contribución al estudio de la influencia de los incendios forestales en las características de la materia orgánica del suelo. II: Transformaciones del humus por ignición en condiciones controladas de laboratorio. Rev. d'Ecol. Biol. Sol. 21, 145-160.

Almendros G, Martín F. and González-Vila, F. J. (1988) Effects of fire on humic and lipid fractions in a Dystric Xerochrept in Spain. Geoderma 42, 115-127.

Almendros, G., Sanz, J. and Sobrados, I. (1989) Characterization of synthetic carbohydrate-derived humic-like polymers. Sci. Total Environ. 81/82, 91- 98.

Almendros, G., González-Vila, F. J. and Martin, F. (1990) Fire-induced transformation of soil organic matter from an oak forest. An experimental approach to the effects of fire on humic substances. Soil Sci. 149, 158-168.

Almendros, G. Fründ, R., González-Vila, F. J., Haider, K. M., Knicker, H. andLüdemann H.-D. (1991) Analysis of ${ }^{13} \mathrm{C}$ and ${ }^{15} \mathrm{~N}$ CPMAS NMR-spectra of soil organic matter and composts. FEBS Lett. 282, 119-121.

Almendros, G, González-Vila, F. J., Martin, F., Fründ, R. and Lüdemann, H.-D. (1992) Solid state NMR studies of fire-induced changes in the structure of humic substances. Sci. Total Environ. 117/118, 63-74.

Almendros, G., Martin, F. González-Vila, F. J. and Del Rio, J. C. (1993) The effects of various chemical treatments on the pyrolytic pattern of peat humic acids. J. Analytic. Appl. Pyrol. 25, 137-147.

Almendros, G., Dorado, J., González-Vila, F. J. and Martin, F. (1997) Pyrolysis of carbohydrate-derived macromolecules: its potential in monitoring the carbohydrate signature of geopolymers. J. Analyt. Appl. Pyrol. 40-41, 599-610.

Almendros, G, González-Vila, F. J., Martín, F., Sanz, J. and Álvarez-Ramis, C. (1998) Appraisal of pyrolytic techniques on different forms of organic matter from a cretaceous basement in central Spain. Organic Geochem. 28, 613-623.

Almendros, G., González-Vila, F. J., Dorado, J., Sanz J., Alvarez-Ramis, C., Martin, F. and Stuchlik L. (1999) Molecular characterization of fossil organic matter in Glyptostrobus europaeus remains from the Orawa basin (Poland). Comparison of pyrolytic techniques. Fuel 78, 745-752.

Almendros, G., Knicker, H. and González-Vila, F. J. (2002) Rearrangement of carbon and nitrogen forms in peat after peat laboratory heating as determined by solid state ${ }^{13} \mathrm{C}$-and ${ }^{15} \mathrm{~N}-\mathrm{NMR}$ spectroscopies. Organic Geochem. (in press).

Athias-Binche, F. and Saulnier, L. (1986) Modalités de la cicatrisation des écosistémes méditerranéens aprés incendie, cas de certains arthropodes du sol. 1. Introduction, stations d'etude. Vie Milieu 36, $117-124$.

Balesdent, J., and Mariotti, A. (1996) Measurement of soil organic matter turnover using ${ }^{13} \mathrm{C}$ natural abundance. In: T. W. Boutton and S. I. Yamasaki (eds), Mass Spectrometry of Soils. Dekker, New York.

Batjes, N. H. (1996) Total carbon and nitrogen in the soils of the world. Eur. J. Soil Sci. 47, 151-163.

Benzing-Purdie, L. M. and Ripmeester, J. A. (1983) Melanoidins and soil organic matter: evidence of strong similarities revealed by ${ }^{13} \mathrm{C}$ CP-MAS NMR. Soil Sci. Soc. Am. J. 47, 56-61.

Benzing-Purdie, L. M., Ripmeester, J. A. and Preston, C. M. (1983) Elucidation of the nitrogen forms in melanoidins and humic acids by nitrogen- 15 cross polarization-magic angle spinning nuclear magnetic resonance. J. Agric. Food Chemist. 31, 913-915.

Benzing-Purdie, L. M., Cheshire, M. V., Williams, B. L., Sparling, G. P., Ratcliffe, C. I. and Ripmeester, J. A. (1986) Fate of $\left[{ }^{15} \mathrm{~N}\right]$ glycine in peat as determined by ${ }^{13} \mathrm{C}$ and ${ }^{15} \mathrm{~N}$ CP-MAS NMR spectroscopy. J. Agric. Food Chemist. 34, 170-176.

Bird, M. I., Moyo, C., Veenendal, E. M., Lloyd, J and Frost, P. (1999) Stability of elemental carbon in savanna soil. Global Bigeochem. Cyc. 13, 923-932.

Boon, J. J. and de Leeuw, J. W. (1987) Amino acid sequence information in proteins and complex proteinaceous material revealed by pyrolysis-capillary gas chromatography-low and high resolution mass spectrometry. J. Analyt. Appl. Pyrol. 11, 313-327. 
Caldararo, N. (2002) Human ecological intervention and the role of forest fires in human ecology. Sci. Total Environ. 292, 141-165.

Cheshire, M. V., Williams, B. L., Benzing-Purdie, L. M., Ratcliffe, C. I. and Ripmeester, J. A. (1990) Use of NMR spectroscopy to study transformations of nitrogenous substances during incubation of peat. Soil Use and Manag. 6, 90-92.

Chouliaras, N., Vedy. J. C. and Portal. J. M. (1975) Fractionnement et caractérisation de la matière organique dan les rendsines. Bull. de l'Inst. Nat. Polytech. Nancy 17, 65-74.

Clinton, P. W., Newman, R. H. and Allen, R. B. (1996) Immobilization of ${ }^{15} \mathrm{~N}$ in forest litter studied by ${ }^{15} \mathrm{~N}$ CPMAS NMR spectroscopy. Eur. J. Soil Sci. 46, 551-556.

De Bano, L. F., Mann, L. D., and Hamilton D. A. (1970) Translocation of hydrophobic substances into soil by burning organic litter. Soil Sci. Soc. Am. Proc. 34, 130-133.

De Bano, L. F., Savage, S. M. and Hamilton, D. A. (1976) The transfer of heat and hydrophobic substances during burning. Soil Sci. Soc. Am. J. 40, 779-782.

De Bano, L. F., Dunn P. H., and Conrad, D. A. (1977a) Fire's effect on physical and chemical properties of chaparral soils. Proc. Symp. Environmental Consequences of Fire and Fuel Management in Mediterranean Ecosystems. USDA Forest Service, CA, pp. 65-74.

De Bano, L. F., Mann, L. D. and Hamilton, D. A. (1977b). Fire's effects on physical and aggregate stability in hydrophobic soil. In: Forest (ed.), Proceedings Symposium on the Environmental Consequences of Fire and Fuel Management Mediterranean Ecosystems. USDA Forest Service, pp. 65-74.

Del Rio, J. C., García-Mollá, J., González-Vila, F. J and Martín, F. (1993) Flash pyrolysis-gas chromatography of the kerogen and asphaltene fractions isolated from a sequence of oil shales. J. Chromatogr. 657, 119-122.

Dennis L. W., Maciel G. E., Hatcher P. G. and Simoneit B. R. T. (1982) ${ }^{13}$ C Nuclear magnetic resonance studies of kerogen from Cretaceous black shales thermally altered by basaltic intrusions and laboratory simulations. Geochim. Cosmochim. Acta 46, 901-907.

Derenne, S., Largeau, C. and Taulelle, F. (1993) Occurrence of non-hydrolysable amides in the macromolecular constituent of Scenedesmus quadricauda cell wall as revealed by ${ }^{15} \mathrm{~N}$ NMR: origin of $n-$ alkylnitriles in pyrolysates of ultralaminae-containing kerogens. Geochim. Cosmochim. Acta 57, $851-857$.

Derenne, S. and Largeau, C. (2001) A review of some important families of refractory macromolecules: composition, origin, and fate in soils and sediments. Soil Sci. 166, 833-847.

Dunn, R. and Conrad, C. E. (1977) Fire's effect on physicai and chemical properties of chaparral soils. In: Proceedings Symposium Environmental Consequences of Fire and Fuel Management in Mediterranean Ecosystems. USDA Forest Service, pp. 65-74.

Durand, B. E. (1980) In: Kerogen (ed.), Insoluble Organic Matter from Sedimentary Rocks. Technip, Paris.

Ellis, G. P. (1959) The Maillard reaction. Adv. Carbohyd. Chem. 14, 63-134.

Ekman, R. (1979). Modified resin acids in the reaction zone of Fomes annosum affected sapwood of Norway Spruce. Acta Acad. Aboensis, Ser. B. 39, 1-7.

Feather, M. S. and Harris, J. F. (1973) Dehydration reactions of carbohydrates. Adv. Carbohyd. Chem. Biochem. 28, 161-224.

Fengel, D. and Wegener, G. (1984) Wood Chemistry, Ultrastructure, Reactions. Walter de Gruyter, Berlin. Fernández, I., Cabaneiro, A. and Carballas, T. (1997) Organic matter changes immediately after a wildfire in an Atlantic forest soil and comparison with laboratory soil heating. Soil Biol. Biochem. 29, 1-11.

Fründ, R. and Ludemann, H.-D. (1989) The quantitative analysis of solution and CPMAS-C-13 NMR spectra of humic material. Sci. Total Environ. 81/82, 157-168.

Gerasimowicz, W., Byler, D. and Susi, H., (1986) Resolution-enhanced FT-IR of soils constituents: humic acid. Appl. Spectroscopy 40, 504-507.

Giovannini, G., Luchessi, S., Cerevelli, S. (1983) Water-repellent substances and aggregate stability in hydrophobic soil. Soil Sci. 135, 110-113.

Giovannini, G. and Lucchesi, S. (1984) Effect of fire on hydrophobic and cementing substances of soil aggregates. Soil Sci. 136, 231-236.

Giovannini, G., Lucchesi S., and Giachetti M. (1987) The natural evolution of a burned soil: a three-year investigation. Soil Sci. 143, 220-226 
Giovannini, G., Luchessi, S. and Giachetti, M. (1988) Effect of heating on some physical and chemical parameters related to soil aggregation and erodibility. Soil Sci. 146, 255-261.

Glaser, B., Haumaier, L., Guggenberger, G. and Zech, W. (1998) Black carbon in soils: the use of benzenecarboxylic acids as specific markers. Organic Geochem. 29, 811-819.

Golchin, A., Clarke, P., Baldock, J. A., Higashi, T., Skjemstad, J. O. and Oades, J. M. (1997a) The effects of vegetation and burning on the chemical composition of soil organic matter in a volcanic ash soil shown by ${ }^{13} \mathrm{C}$ NMR spectroscopy. I. Whole soil and humic acid fraction. Geoderma 76, 155-174.

Golchin, A., Baldock, J. A., Clarke, P., Higashi, T. and Oades, J. M. (1997b) The effects of vegetation and burning on the chemical composition of soil organic matter of a volcanic ash soil as shown by ${ }^{13} \mathrm{C}$ NMR spectroscopy. II. Density fractions. Geoderma 76, 175-192.

Goldberg, E. D. (1985) Black Carbon in the Environment. Wiley, New York.

González-Vila, F. J., Almendros, G, Tinoco, P. and Rodriguez, J. (2001a) Nitrogen speciation and pyrolytic patterns of ${ }^{15} \mathrm{~N}$-labelled soil and compost fractions. J. Analyt. Appl. Pyrol. 58-59, 329-339

González-Vila, F. J., Amblés, A., Del Rio, J. C. and Grasset, L (2001b) Characterisation and differentiation of kerogens by pyrolytic and chemical degradation techniques. J. Analyt. Appl. Pyrol. 58/59, 315-328.

González-Vila, F. J., Tinoco, P., Almendros, G., Martín, F. (2001c) Py-GC-MS analysis of the formation and degradation stages of charred residues from lignocelulosic biomass. J. Agricul. Food Chem. 49, 1128- 1131.

González-Vila, F. J., González, J. A., Polvillo, O., Almendros G. and Knicker, H. (2002) Nature of refractory forms of organic carbon in soils affected by fires. Pyrolytic and spectroscopic approaches. In: Proceedings IV International Conference on Forest Fires Research. Coimbra, Portugal.

Greenland, D. J. (1971) Interactions between humic and fulvic acids and clays. Soil Sci. 111, 34-41.

Grossi, V., Baas, M., Schogt, N., Breteler, W. C. M., de Leeuw, J. W. and Rontani, J. F. (1996) Formation of phytadienes in the water column: myth or reality? Organic Geochem. 24, 833-839.

Guckert, A., Roger, P. and Jacquin, F. (1968) Contribution a l'utilisation des techniques radiositopiques por l'etude de la matière organique du sol. Bull. Ecole Nationale Superieur Agronomique 10, 69-100.

Gustafsson, O. and Gschwend, $\mathrm{Ph}$. M. (1998) The flux of black carbon to surface sediments on the New England continental shelf. Geochim. Cosmochim. Acta 62, 465-472.

Haslam, S. F. I., Chudek, J. A., Goldspink, C. R. and Hopkins, D. W. (1998) Organic matter accumulation following fires in a moorland soil chronosequence. Global Change Biol. 4, 305-313.

Hatcher, P. G., Schnitzer, M., Vasallo, A. M. and Wilson, M. A. (1989) The chemical structure of highly aromatic humic acids in three volcanic ash soils as determined by dipolar dephasing NMR studies. Geochim. Cosmochim. Acta 53, 125-130

Haumaier, L. and Zech, W. (1995) Black carbon - possible source of highly aromatic components of soil humic acids. Organic Geochem. 23, 191-196.

Hayes M. H. B., MacCarthy P., Malcolm R. L. and Swift, R. S. (1989) Humic Substances. II. In the Search of Structure. John Wiley and Sons, New York

Hedges, J. L. (1978) The formation and clay reactions of melanoidins. Geochim. Cosmochim. Acta 42 , $69-76$.

Hedge J. E. (1953) Chemistry of browning reactions in model systems. J. Agricul. Food Chem. 928-943.

Ikan, R, Rubinsztain, Y., Nissenbaum, A. and Kaplan, I. R. (1996) Geochemical aspects of the Maillard reaction. In: R. Ikan (ed.). The Maillard Reaction. Consequences for the Chemical and Life Sciences. John Wiley and Sons, Chichester, pp. 1-26.

Ishiwatari, M., Ishwatari, R., Sakashita, H., Tatsumi, T. and Tominaga, H (1990) The effects of preheating treatment on the pyrolysis of chloropyll a. Simulation of diagenetic processes in kerogen formation. Chem. Lett. 6, 875-878.

Ketterings, Q. M., Bigham, J. M. and Laperche, V. (2000) Changes in soil mineralogy and texture caused by the slash and burn fires in Sumatra, Indonesia. Soil Sci. Soc. Am. J. 64, 1108-1117.

Knicker, H., Fründ, R. and Lüdemann, H.-D. (1993) The chemical nature of nitrogen in native soil organic matter. Naturwissenschaften 80, 219-221.

Knicker, H. and Lüdemann, H.-D. (1995) N-15 and C-13 CPMAS and solution HR NMR studies on the chemical modifications of $\mathrm{N}-15$ enriched plant material during 600 days of microbial degradation. Organic Geochem. 23, 329-341. 
Knicker, H., Hatcher, P. G. and Scaroni, A. W. (1995) Solid-state ${ }^{15}$ N NMR spectroscopy of coal. Energy and Fuel 9, 999-1002.

Knicker, H., Almendros, G., González-Vila F. J., Martin, F. and Lüdemann, H.-D. (1996) ${ }^{13} \mathrm{C}-$ and ${ }^{15} \mathrm{~N}-$ NMR spectroscopic examination of the transformation of organic nitrogen in plant biomass during thermal treatment. Soil Biol. Biochem. 28, 1053-1060.

Knicker, H., Fründ, R. and Lïdemann, H.-D. (1997) Characterization of the nitrogen in plant composts and native humic material by natural abundance N-15 CPMAS and solution spectra. In: M. A. Nanny, R. A. Minear and J. Lenheer (eds), Nuclear Magnetic Resonance Spectroscopy in Environmental Chemistry. Oxford University Press, London, pp. 272-294.

Knicker, H. and Hatcher, P. G. (1997) Survival of protein in organic-rich sediments - possible protection by encapsulation in organic matter. Naturwissenschaften 84, 231-234.

Knicker, H. (2000) Biogenic nitrogen in soils as revealed by solid-state ${ }^{13} \mathrm{C}$ and ${ }^{15} \mathrm{~N}$ NMR spectroscopy. J. Environ. Qual. 29, 715-723.

Knicker, H. and Skjemstad, J. O. (2000) Carbon and nitrogen functionality in protected organic matter of some Australian soils as revealed by solid-state ${ }^{13} \mathrm{C}$ and ${ }^{15} \mathrm{~N}$ NMR. Aust. J. Soil Sci. 38, 113-127.

Knicker, H., Schmidt, M. W. I. and Kögel-Knabner, I. (2000) Immobilization of peptides in fine particle size separates of soils as revealed by NMR spectroscopy. Soil Biol. Biochem. 32, 241-252

Knicker, H., Hatcher, P. G. and González-Vila, F. J. (2002) Formation of heteroaromatic nitrogen after prolonged humification of vascular plant remains as revealed by Nuclear Magnetic Resonance spectroscopy. J. Environ. Qual. 31, 444-449.

Kodama, H. and Schnitzer, M. (1970) Kinetics and mechanism of the thermal decomposition of fulvic acid. Soil Sci. 109, 265-271.

Kögel-Knabner I. (1997) ${ }^{13} \mathrm{C}$ and ${ }^{15} \mathrm{~N}$ NMR spectroscopy as a tool in soil organic matter studies. Geoderma 80, 243-270.

Kuhlbusch, T. A. J. (1998) Black carbon and the carbon cycle. Science 280, 1903-1904.

Kuhlbusch, T. A. J., Andreae, M. O., Cachier, H., Goldammer, J. G., Lacaux, J.-P., Shea, R. and Crutzen, P. J. (1996) Black carbon formation by savanna fires: measurements and implications for the global carbon cycle. J. Geophys. Res. [Atmos.] 101, 23651-23665.

Levine, J. S., Cofer, W. R., Cahoon, D. R. and Winstead, E. L. (1995) Biomass burning: a driver for global change. Environ. Sci. Technol. 29, 120A-125A.

Lowe, L. E. (1975) Fractionation of acid-soluble components of soil organic matter using polyvinyl pyrrolydone. Can. J. Soil Sci. 56, 119-126.

Maillard, M. L.-C. (1916) Synthèse des matières humiques par action des acides amines sur les sucres reducteurs. Annales de Chimie 5, 258-317.

Martin, F., Saíz-Jiménez, C. and González-Vila, F. J. (1979) Pyrolysis-gas chromatography-mass spectrometry of lignins. Holzforschung 33, 210-212.

Martín, F., Saiz-Jiménez, C. and González-Vila, F. J. (1981) The persulfate oxidation of a soil humic acid. Soil Sci. 132, 200-203.

Martin, F. and González-Vila, F. J. (1983) Pyrolysis of a soil humic acid and of their hydrolyzed and methylated products. Zeit. Pflanz. Bodenkunde 146, 663-659.

Mathur S. P. (1972) Infrared evidence of quinones in soil humus. Soil Sci. 113, 136-139.

Matsuda, K. and Schnitzer, M. (1972) The permanganate oxidation of humic acids extracted from acid soils. Soil Sci. 114, 185-193.

Maximov, O. B., Shvets, T. V. and Elkin, Yu. N. (1977) On permanganate oxidation of humic acids. Geoderma 19, 73-78.

Mehlich, A. (1948) Determination of cation and anion exchange properties of soils. Soil Sci. 66, 429445.

Merlet, D. (1971) Mise au point tecnique concernant l'extraction et la caracterisation des composés organiques dans les sols. Centre de Pedologie Biologique. CNRS Nancy. Doc. no. 15.

Monnier, G., Turc, L. and Jeanson-Luusinang, C. (1962) Une méthode de fractionnement densimetrique par centrifugation des matières organiques du sol. Annales Agronomiques 13, 55-63.

Nguyen, R. T. and Harvey, H. R. (1998) In: B. A. Stankiewicz and P. F. Van Bergen (eds), Nitrogencontaining Macromolecules in the Bio- and Geosphere. ACS Symposium Series 707, American Chemical Society, Washington, DC, pp. 88-112. 
Parker, J. L., Fernández, I. J., Rustad, L. E. and Norton, S. A. (2001) Effects of nitrogen enrichment, wildfire, and harvesting on forest soil carbon and nitrogen. Soil Sci. Soc. Am. J. 65, 1248-1255.

Pastorova I., Botto R. E., Arisz P. W. and Boon J. J. (1994) Cellulose char structure: a combined analytical Py-GC-MS, FTIR, and NMR study. Carbohyd. Res. 262, 27-47.

Popoff, T. and Theander, O. (1972) Formation of aromatic compounds from carbohydrates. Part I. Reaction of D-glucuronic acid, D-galacturonic acid, D-xylose, and L-arabinose in slightly acidic, aqueous solution. Carbohyd. Res. 22, 135-149.

Popoff T. and Theander O. (1976) Formation of aromatic compounds from carbohydrates. Part III. Reaction of D-glucose and D-fructose in slightly acidic, aqueous solution. Acta Chem. Scand. 30, 397-402.

Post, W. M., Peng T. H., Emanuel, W. R., King, A. W., Dale, V. H. and De Angelis, D. L. (1990) The global carbon cycle. Am. Sci. 78, 310-326.

Potthast, A., Schiene, R. and Fischer, K. (1996) Structural investigations of N-modified lignins by ${ }^{15} \mathrm{~N}$ NMR spectroscopy and possible pathways for formation of nitrogen containing compounds related to lignin. Holzforschung 50, 554-562.

Prentice, I. C., Farquhar, G. D., Fasham, M. J. R., Goulden, M. L., Heimann, M., Jaramillo V. J., Kheshgi, H. S., Le Quéré, C., Scholes, R. J. and Wallace, D. W. R. (2001) The carbon cycle and atmospheric carbon dioxide. In: J. T. Houghton, Y. Ding, D. J. Griggs, M. Noguer, P. J. van der Linden, X. Dai, K. Maskell and C. A. Johnson (eds), Climate Change 2001: The Scientific Basis. Cambridge University Press, Cambridge, UK.

Preston, C. M., Ripmeester, J. A., Mathur, S. P. and Lévesque, M. (1986) Application of solution and solid-state multinuclear NMR to a peat-based composting systems for fish and crab scrap. Can. $J$. Spectroscopy 31, 63-69.

Preston, C. M. (1992) The application of NMR to organic matter inputs and processes in forest ecosystems of the Pacific Northwest. Sci. Total Environ. 3, 107-120.

Ralph J. and Hatfield R. D. (1991) Pyrolysis-GC-MS characterization of forage materials. J. Agricul. Food Chem. August 1426-1437.

Remmler, M. and Kopinke, F. D. (1995) Thermal conversion of hydrocarbons on solid matrices. Thermochim. Acta 263, 113-121.

Rosenfeld, A. and Kak, A. (1982) Digital Image Processing, Vol. 1. 2nd edn. Academic Press, Amsterdam.

Savage, S. M., Osborn, J., Letey, J. and Heaton, C. (1972) Substances contributing to fire-induced water repellency in soil. Soil Sci. Soc. Am. Proc. 36, 674-678.

Savage, S. M. (1974) Mechanism of fire-induced water repellency in soil. Soil Sci. Soc. Am. Proc. 38 , $652-657$.

Schmidt, M. W. I., Skjemstad, J. O., Gehrt, E. and Kögel-Knabner, I. (1999) Charred organic carbon in German chernozemic soils. Eur. J. Soil Sci. 50, 351-365.

Schnitzer, M. and Khan, S. U. (eds). (1972) Humic Substances in the Environment. Dekker, New York.

Schnitzer, M. (1974) The methylation of humic substances. Soil Sci. 117, 94-102.

Schnitzer, M. (1977) Recent findings on the characterization of humic substances extracted from soils from widely differing climatic zones. Proceedings International Symposium on Soil Organic Matter, 3rd, Braunschweig, 6-10 Sept. 1976, Vol. II. International Atomic Energy Agency, pp. 117- 132.

Schnitzer, M. (1985) Nature of nitrogen in humic substances. In: R. G. Aiken, D. M. Mcknight, R. L. Wershaw and P. MacCarthy (eds), Humic Substances in Soil Sediment and Water, Chap. 12. Wiley, pp. 303-325.

Scholl, D. B. (1975) Soil wettability and fire in Arizona chaparral. Soil Sci. Soc. Am. Proc. 39, 356-361.

Schulten, H.-R. and Schnitzer, M. (1998) The chemistry of soil organic nitrogen: a review. Biol. Fertil. Soils 26, 1-15.

Shindo, H., Matsui, Y, and Higashi, T. (1986a) Humus composition of charred plant residues. Soil Sci. Plant Nutr. 32, 475-478.

Shindo, H., Matsui, Y. and Higashi, T. (1986b) A possible source of humic acids in volcanic ash soils in Japan - charred residue of Miscanthus sinensis. Soil Sci. 141, 8-87.

Shindo, H. (1991) Elementary composition. Humus composition and decomposition in soil of charred grassland plants. Soil Sci. Plant Nutr. 37, 651-657. 
Shyoya, M. and Ishiwatari, R. (1983) Laboratory thermal conversion of sedimentary lipids to kerogenlike matter. Organic Geochem. 5, 7-12.

Simoneit, B. R. T. and Mazurek, M. A. (1982) Organic matter of the troposphere - II. Natural background of biogenic lipid matter in aerosols over the rural western United States. Atmos. Environ. 16, 2139-2159.

Skjemstad, J. O., Clarke, P., Taylor, J. A., Oades, J. M. and McClure, S. G. (1996) The chemistry and nature of protected carbon in soil. Aust. J. Soil Res. 34, 251-271.

Skjemstad, J. O., Clark, P., Golchin, A. and Oades, H. M. (1997) Characterization of soil organic matter by solid state ${ }^{13} \mathrm{C}$ NMR spectroscopy. In: G. Cadisch and K. E. Giller (eds), Driven by Nature: Plant Litter Quality and Decomposition. CAB International, Wallingford, pp. 253-271.

Smith, D., and G. Bowes. (1974) Loss of some elements in fly ash during old-fields burning Southern Ontario. Can. J. Soil Sci. 54, 215-214.

Solum, M. S., Pugmire, R.,J., Grant, D. M., Fletcher, T. H. and Solomon, P. (1989) Solid-state carbon-13 NMR studies of coal char structure evolution. Soc. Div. Fuel Chem. 34, 1337-1346.

Stevenson, F. J. (ed.). (1982) Humus Chemistry. Genesis, Composition, Reactions. Wiley, New York.

Swan, E. P. (1995) Identity of a hydrocarbon found in a forest soil. Forest Prod. J. 15, 272.

Takeda, H., Schuller, W. and Lawrence, R. W. (1998) Novel ring openings in methyl levopimarate. $J$. Organic Chem. 33, 3719-3722.

Thorn, K. A., Folan, D. W., Arterburn, J. B., Mikita, M. A. and MacCarthy, P. (1989) Application of INEPT nitrogen-15 and silicon-29 nuclear magnetic resonance spectrometry to derivatized fulvic acids. Sci. Total Environ. 81/82, 209-218.

Tinoco, P. (2000) Caracterización molecular de la materia orgánica de suelos afectados por distintos tipos de degradación en la Comunidad de Madrid. PhD. Universidad Autónoma de Madrid.

USDA (1972) Soil Survey Laboratory methods and procedures for collecting soil samples. Soil Conservation Service, Report 1.

van der Marel, H. W and Beutelspacher, H. (1976) Atlas of Infrared Spectroscopy of Clay Minerals and their Admixtures. Elsevier, Amsterdam.

Van Krevelen, D. W. (1950) Graphical-statistical method for the study of structure and reaction processes of coal. Fuel 29, 269-284.

Vega, J. A., Bará, S. and Gil. M. (1985) Algunos aspectos a corto plazo del fwgo prescrito en pinares de Galicia. In: Estudios sobre prevención y efectos ecológicos de los incendios forestales. Ministerio de Agricultura, pesca y Alimentación/lnstituto. Nacional para la Conservación de la Naturaleza, Madrid, pp. 103-120.

Vega, J. A. (1986) La investigación sobre incendios forestrales en España. Revision bibliografica, Proceedings Symposium. Bases Ecológicas para la Gestión Ambiental (Diputacion de Barcelona), pp. 17-24.

Vega, J. A., (1985) Datos preliminares sobre el comportamiento del fuego prescrito para la reducción de combustible bajo pinares de Galicia. In: Ministerio de Agricultura (ed.), Estudios sobre Prevención y Efectos Ecológicos de los Incendios Forestales, Madrid, pp. 51-57.

Viro, P. J., (1974) Effects of forest fires on soil. In: T. T. Kolzlowski and C. E. Alhgreen (eds), Fire and Ecosystems. Academic Press, New York, pp. 8-45.

Wang, S. -H. and P. R. Griffiths, P. R. (1985) Resolution enhancement of diffuse reflectance i. r. spectra of coals by Fourier self-deconvolution 1. C-H stretching and bending modes. Fuel 64: 229-236.

Wang, N and Low, M. J. D. (1990) The pyrolysis of a lignin. Report CA Section: 43 (Cellulose, Lignin, Paper, Other Wood Products). Energy Res. Abstr. 15, 13 pp.

Wilson, M. A. (1987) NMR Techniques and Applications in Geochemistry and Soil Chemistry. Pergamon, Oxford, UK.

Witanowsk, M., Stefaniak, L. and Webb, G. (1993) Nitrogen NMR spectroscopy. In: G. A. Webb (ed.), Annual Reports on NMR Spectroscopy 25, Academic Press, London.

Wright, J. R. and Schnitzer, M. (1961) An estimate of the aromaticity of the organic matter of a podzol soil. Nature 4777, 703-704.

Yanagita, T., Jiang, Y. and Matsumoto, S. (1997) Carbohydrate and microbial decomposition of the ricehull charred to different degrees. Nippon Dojo Hiryogaku Zasshi (Japanese) 68, 435-437.

Yang, W. -J., Griffiths, P. R., Byler, D.M. and Susi, H. (1985) Protein conformation by infrared spectroscopy: resolution enhancement by Fourier self-deconvolution. Appl. Spectroscopy 39, 282-287. 
Zinkel, D. F., Rowe, J. W., Zank, L. C., Gaddie, D. W. and Ruckel, E. R. (1989) Unusual resin acids in tall oil. J. Am. Oil Chem. Soc. 48, 833-834.

Zinkel, D. F., Zank, L. C. and Wesolowski, M. F. (1971). Diterpene Resin Acids. USDA Forest Service, Forest Product Laboratory, Madison, Wis., $190 \mathrm{pp}$. 